\title{
Kyrgyz Republic: Selected Issues
}

This paper on Kyrgyz Republic was prepared by a staff team of the International Monetary Fund as background documentation for the periodic consultation with the member country. It is based on the information available at the time it was completed on May 22, 2013. The views expressed in this document are those of the staff team and do not necessarily reflect the views of the government of the Kyrgyz Republic or the Executive Board of the IMF.

The policy of publication of staff reports and other documents by the IMF allows for the deletion of market-sensitive information.

\author{
Copies of this report are available to the public from \\ International Monetary Fund • Publication Services \\ $70019^{\text {th }}$ Street, N.W. • Washington, D.C. 20431 \\ Telephone: (202) 623-7430 • Telefax: (202) 623-7201 \\ E-mail: publications@imf.org Internet: http://www.imf.org
}

\section{International Monetary Fund Washington, D.C.}




\title{
INTERNATIONAL MONETARY FUND
}

May 22, 2013

\section{KYRGYZ REPUBLIC}

\section{SELECTED ISSUES}

\author{
Approved By \\ Middle East and \\ Central Asia \\ Department
}

Prepared By Q. Chen, D. Ostojic, and B. Shukurov

\section{CONTENTS}

TAX POLICY IN THE KYRGYZ REPUBLIC

A. Background __ 4

B. Main Characteristics of the Tax Regime and Tax Performance

C. Tax Incentives _ 10

D. Tax Policy Reform Options__ 14

\section{FIGURES}

1. Revenue from Each Tax 5

2. Tax-to-GDP and GDP per capita___ 5

3. Tax-to-GDP and GDP per capita___ 5

4. VAT Revenue and Imports___ 7

5. VAT Productivity and Efficiency ___ 7

6. PIT and CIT Revenue___ 8

7. New Gross Revenue Tax Rate for Gold-Mining Companies ___ 9

\section{TABLES}

1. Tax Systems in the Region 6

2. Assessment of Typical Tax Incentives 13

\section{REFERENCES}

TRANSMISSION CHANNELS OF MONETARY POLICY IN THE KYRGYZ REPUBLIC _ 18
A. Background
B. Current Monetary Policy Framework 18
C. Transmission Channels of Monetary Policy 23
D. Barriers to Effective Monetary Policy 24 


\section{FIGURES}

1. Inflation and Monetary Aggregates 18

2. Monetary and Exchange Rate Developments __ 19

3. Reserve and Broad Money __ 20

4. REPO-agreements and NBKR Bills__ 21

5. Policy Rate, Growth, and Inflation __ 21

6. Transmission Channels of Monetary Policy___ 23

7. Selected Monetary Indicators, 2001-12 29

\section{TABLES}

1. Inflation and Monetary Aggregates Targets vs Actuals___ 19

2. Comparison of Selected Banking Indicators___ 21

3. Comparison of de jure Central Bank Independence __ 22

BOX

1. General Barriers to Effective Monetary Policy ___ 26

REFERENCES $\quad 30$

EXCHANGE RATE ASSESSMENT AND RESERVE ADEQUACY IN THE KYRGYZ REPUBLIC 32

A. Exchange Rate Assessment __ 32

B. International Reserve Adequacy in the Kyrgyz Republic__ 35

\section{FIGURES}

1. Trade Openness in 2012

2. Growth of Import and Export Prices___ 33

3. Current Account Deficit _ 33

4. NEER and Relative Prices _ 33

5. Kyrgyz Republic Share of World Exports __ 33

6. Gross International Reserves __ 35

7. Main Sources of Gross International Reserves Accumulation __ 36

8. Main Drains on Gross International Reserves__ 36

\section{TABLES}

1. Econometric Assessments of the Real Exchange Rate Disequilibrium _ 34

2. Gross International Reserves __ 37

3. Composite and Calibrates Reserve Adequacy Indicators___ 38

4. Composite and Calibrated Reserve Adequacy Indicators Under Different Scenario _ 40 


\section{FIGURE}

1. Business Environment and Governance 44

BEST PRACTICES FOR ESTABLISHING DEVELOPMENT BANKS 45

\section{FIGURES}

1. Private Credit in the Region, 2011 45

2. Credit by Sectors, 2011 


\section{TAX POLICY IN THE KYRGYZ REPUBLIC ${ }^{1}$}

\section{A. Background}

1. The government of the Kyrgyz Republic is determined to consolidate its finances over the coming years. Therefore, continued strong revenue performance is important. In the short term, introduced tax policy measures and continued tax administration reforms are expected to ensure sufficient revenue. In the medium term, additional tax policy measures, including eliminating some tax incentives, will have to be put in place to ensure sustained revenue growth needed to finance development.

2. This note describes the main elements of the tax regime in the Kyrgyz Republic, looks into tax incentives, and provides some reform options to raise revenues. A detailed assessment of the tax policy system was conducted under the IMF's technical assistance in 2009. In 2011, IMF staff held discussions with the authorities on tax policy measures that could increase revenues. The note draws on these assessments and provides an update on changes since 2009. It also discusses existing tax incentives. Lastly, the note examines tax measures that could raise revenues in the medium term.

\section{B. Main Characteristics of the Tax Regime and Tax Performance}

\section{In 2009, a new tax code was put in place to ease the tax burden on business and} simplify tax procedures. The main changes of the new 2009 tax code included:

- $\quad$ Reducing the number of taxes from 16 to 8.

- Decreasing the value added tax (VAT) rate from 20 to 12 percent.

- Establishing the turnover (sales) tax that replaced the retail sales tax, road tax, and emergency funds.

- Introducing a new property tax.

- Establishing five special tax regimes (mandatory payments, voluntary payment, a simplified single tax, contract-based tax, and free economic zones).

4. Since 2009, no substantial changes have been introduced in the tax code except for some tax incentives and amendments to profit and excise taxes. The introduced tax incentives include: VAT exemptions in agriculture, a new high technologies park tax regime, and some

\footnotetext{
${ }^{1}$ Prepared by Bahrom Shukurov. The note has benefited from comments from Selcuk Caner, Ricardo Fenochietto, and Agustin Roitman from the Fiscal Affairs Department of the IMF.
} 
additions to personal income tax (PIT) exemptions. VAT exemptions on internet and roaming services were removed. The authorities also raised the excise tax rate for tobacco and alcohol products, introduced new gross income tax for gold-mining companies in lieu of profit tax or corporate income tax (CIT), and eliminated the tax on special funds.

\section{Revenue collection has been encouraging with VAT being the main source of revenue}

(Figure 1). Total tax revenue increased to 24 percent of GDP in 2011 from 21 percent of GDP in 2006. After a decline in 2009 (when the rate was reduced), VAT revenue was gradually increasing relative to GDP but still remained below the pre-2009 levels. Collections of income tax increased markedly mainly on account of strong growth in CIT. Social contributions were rising steadily reaching about 5 percent of GDP in 2011.

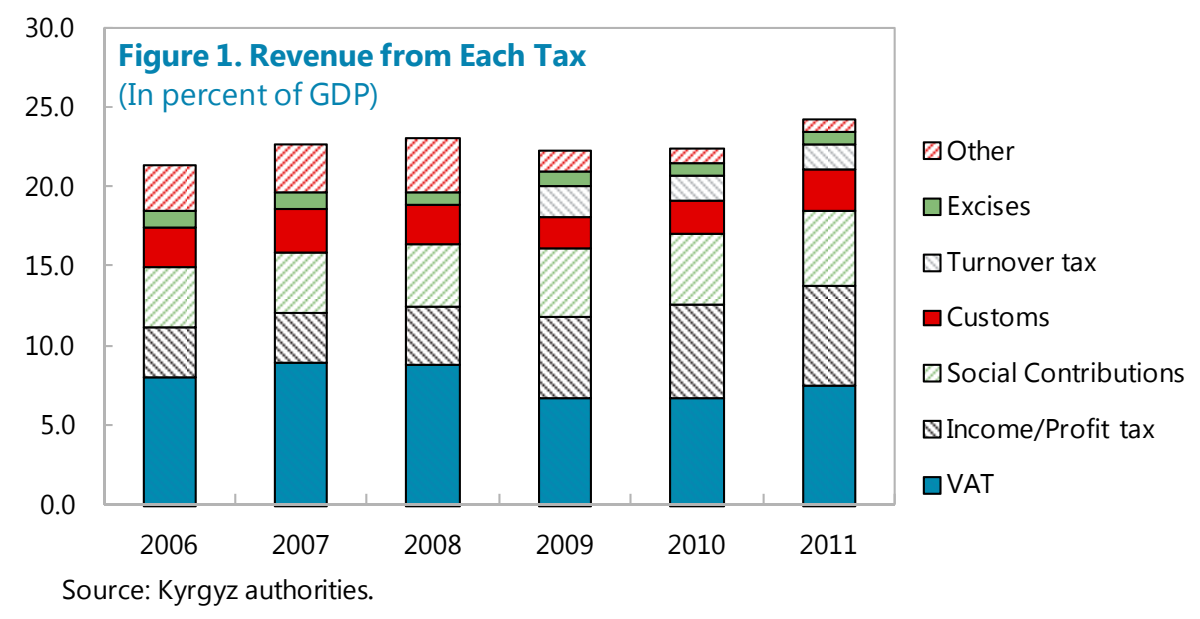

6. At $\mathbf{2 4}$ percent of GDP, tax revenue in the Kyrgyz Republic is not insignificant. Figures below show the relationship between per capita income and the tax-to-GDP ratio. Figure 2 depicts all countries, whereas Figure 3 includes countries with incomes ranging from US\$600 to US\$2,200. The Kyrgyz Republic is above the average compared with other low income countries.

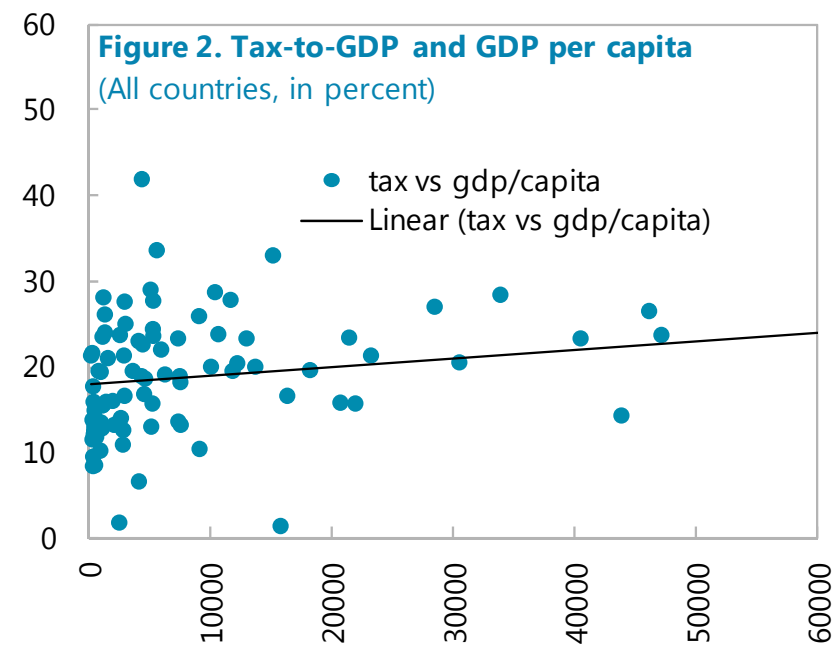

Source: IMF.

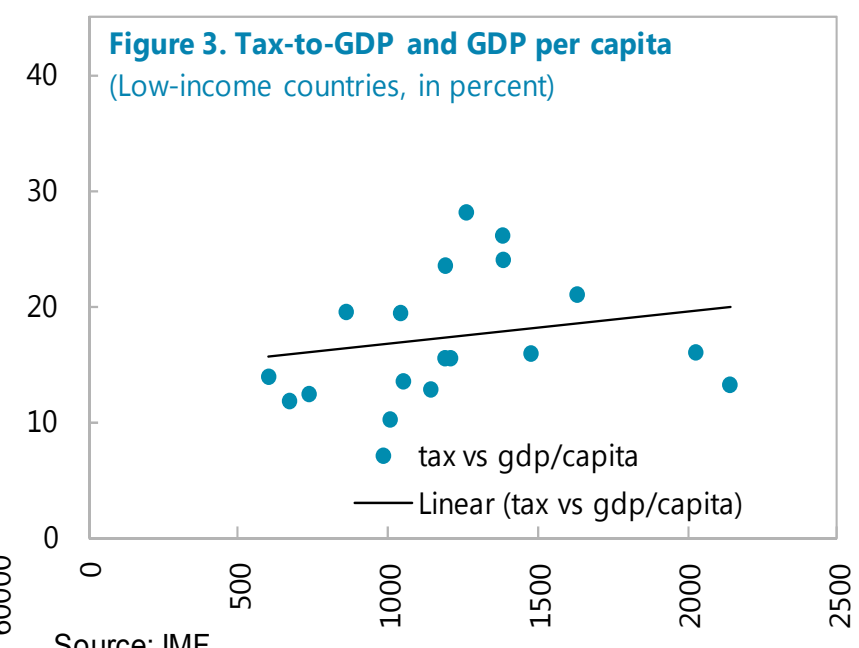


7. The Kyrgyz Republic compares favorably in terms of tax collections, including among countries in the region (Text Table 1). The CIT rate was reduced from 30 percent to 20 percent in 2004 and further down to 10 percent in 2006 to increase competitiveness within the region. With the CIT rate remaining unchanged over the past years, its collection increased to a relatively comfortable level, though some space for further increases exist. Some of the other countries in the region have also seen declines in their CIT rates but the declines were not as substantial as in the Kyrgyz Republic. VAT revenue in the Kyrgyz Republic declined compared to 2008, in response to reduced rates, which were brought in line with VAT rates in Kazakhstan. Armenia, Azerbaijan, and Georgia, did not reduce their VAT rates, which were maintained at 18-20 percent over the past years. An increase in VAT productivity was most significant in the Kyrgyz Republic. VAT productivity in other countries has also increased except in Kazakhstan.

Text Table 1. Kyrgyz Republic: Tax Systems in the Region

\begin{tabular}{|c|c|c|c|c|c|c|c|c|c|c|c|c|}
\hline & \multicolumn{2}{|c|}{ Tax Revenue to GDP } & \multicolumn{2}{|c|}{ CIT Revenue to GDP } & \multicolumn{2}{|c|}{ VAT Revenue to GDP } & \multicolumn{2}{|c|}{ VAT productivity } & \multicolumn{2}{|c|}{ CIT rate } & \multicolumn{2}{|c|}{ VAT rate } \\
\hline & 2006 & 2011 & 2006 & 2011 & 2006 & 2011 & 2006 & 2011 & 2006 & 2011 & 2006 & 2011 \\
\hline Armenia & 14.5 & 16.7 & 2.5 & 2.6 & 6.2 & 8.0 & 31 & 40 & 20 & 20 & 20 & 20 \\
\hline Azerbajan 1/ & 17.8 & 13.7 & 7.3 & 4.2 & 3.9 & 4.3 & 22 & 24 & 22 & 20 & 18 & 18 \\
\hline Georgia & 19.2 & 25.2 & 2.5 & 6.4 & 9.7 & 11.4 & 54 & 64 & 20 & 15 & 18 & 18 \\
\hline Kazakhstan 1/ & 16.3 & 12.1 & 10.7 & 8.2 & 4.8 & 3.2 & 32 & 26 & 30 & 20 & 15 & 12 \\
\hline Kyrgyz Republic & 22.6 & 24.2 & 1.0 & 3.2 & 8.0 & 7.5 & 40 & 62 & 10 & 10 & 20 & 12 \\
\hline Tajikistan & 16.5 & 19.3 & 0.9 & 1.3 & 7.3 & 8.4 & 36 & 46 & 25 & $15-25$ & 20 & 18 \\
\hline
\end{tabular}

1/ Excludes oil revenue.

Sources: Kyrgyz authorities and IMF staff estimates.

\section{Strong growth in VAT is not only attributed to the buoyant increase in imports, but} also improved tax collection. The Kyrgyz Republic is one of the largest recipients of remittances (relative to GDP) in the world. In addition, the country benefits from trading activity that takes place in the trading "corridor" from China to Kazakhstan and Russia. Imports in the Kyrgyz Republic increased from 79 percent of GDP in 2006 to 87 percent of GDP in 2011. VAT revenue, as mentioned above, declined, mostly because of reduced rates (Figure 4). The decline was limited by improved VAT productivity and VAT efficiency, which grew substantially over the last years (Figure 5), helped by better tax compliance and more effective tax collection. ${ }^{2}$ However, the VAT refund mechanism has largely remained weak.

\footnotetext{
${ }^{2}$ VAT productivity is the ratio of VAT revenue to GDP divided by the VAT rate. VAT efficiency, which is a better indicator of VAT performance, is the ratio of VAT revenues to consumption divided by the VAT rate.
} 

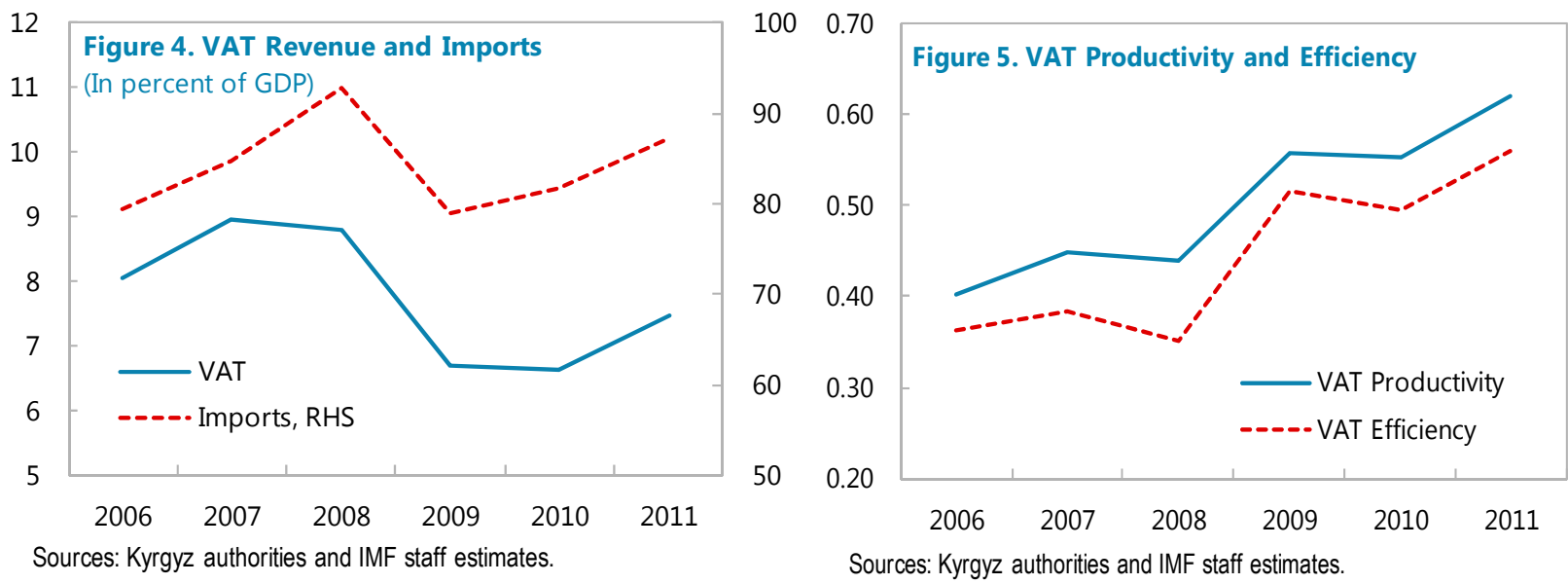

\section{The turnover (sales) tax was introduced to compensate for the reduction in the VAT}

rate. The tax rate is 1.5 percent for commercial activities and 2.5 percent for other activities for taxpayers under the VAT system, or about 90 percent of all registered taxpayers ( 2.5 percent and 3.5 percent, respectively, for taxpayers who are not in the VAT system). This tax simplified the tax system to some extent, because it replaced the previous retail sales tax, road tax, and emergency funds. However, and even at the low rates, the turnover tax negatively affects the competitiveness of businesses in the Kyrgyz Republic. Because of the cascading nature, the effects of a low rate are multiplied when goods pass from one business to another, thus causing distortions to economic activity. With this tax, businesses are less competitive in both domestic and international markets. In addition, the turnover tax cannot be refunded because identifying the incidence of the tax in the product cost is not feasible.

\section{Excises as a share of total tax revenue declined from $\mathbf{5}$ percent of GDP in 2006 to} 3.3 percent in 2011 because of low rates and effects of inflation. Excises in the Kyrgyz Republic are imposed on certain domestically produced and imported goods, such as oil products, tobacco products, and alcoholic beverages. In 2011, excises accounted for 3.3 percent of tax revenue, a decline by about 2 percentage points since 2006. A major part of excises is handled by customs administration that collects the revenue at the borders. Therefore, the low revenue can be attributed to low rates. In addition, with most excises being specific (based on quantity) rather than ad valorem (based on value), revenue from this tax has been devalued by inflation. At the same time, given that specific excises are more predictable and easier to administer, they may be preferable to ad valorem excises. A combined, specific/ad valorem system for tobacco and alcohol products with higher rates was introduced recently to increase revenues from excises. The excise rate for oil products, in particular gasoline, is low at KGS 3000 (about US\$60) per ton (e.g. in Belarus, the rate is five times higher than in the Kyrgyz Republic; in Slovakia, the rate is eight times higher; in the eurozone countries, the average rate is more than 10 times higher).

\section{Customs duties and other taxes on international trade account for $\mathbf{1 1}$ percent of tax} revenue but may decline in the future. Customs duties are levied on a few kinds of imports, 
namely vehicles and goods imported through the simplified customs clearance process (weight-based customs duties). ${ }^{3}$ The latter ensures low levels of customs duties, which together with specific geographical location, being a WTO member, and free trade agreements with Russia and Kazakhstan, provides an advantage for the Kyrgyz Republic in trade of goods from China. However, the weight-based valuation system results in a systematic underassessment of imports and therefore contributes to revenue loss. Recently, the authorities raised duties from 15 cents per kilogram to 35 cents and moved some goods to the price-based valuation system. This is expected to increase revenue but also to smooth potential future shocks, which could stem from the Kyrgyz Republic's accession to the Belarus-Kazakhstan-Russia Custom Union (CU), or in case free trade agreements between the Kyrgyz Republic and Kazakhstan and Russia are annulled. In both cases, transit activity from China would be reduced.

12. The revenue from PIT and CIT increased considerably over the last years (Figure 6). In 2011, these taxes accounted for 26 percent of total tax revenue, an increase from 14 percent in 2006. With the 2009 agreement between the government and the Kumtor mining company, CIT was the main contributor to this increase. ${ }^{4}$ Recently, the authorities introduced a new revenue tax (linked to gold price movements) for gold-mining companies in lieu of CIT (Figure 7). Both CIT and PIT have rates at 10 percent, which is low by regional standards (the PIT rate is one of the lowest in the world). Employers and employees also pay social contributions at the rate of 17.25 and 10 percent, respectively. As many taxpayers participate in the low-yielding voluntary patent regime, they are outside of

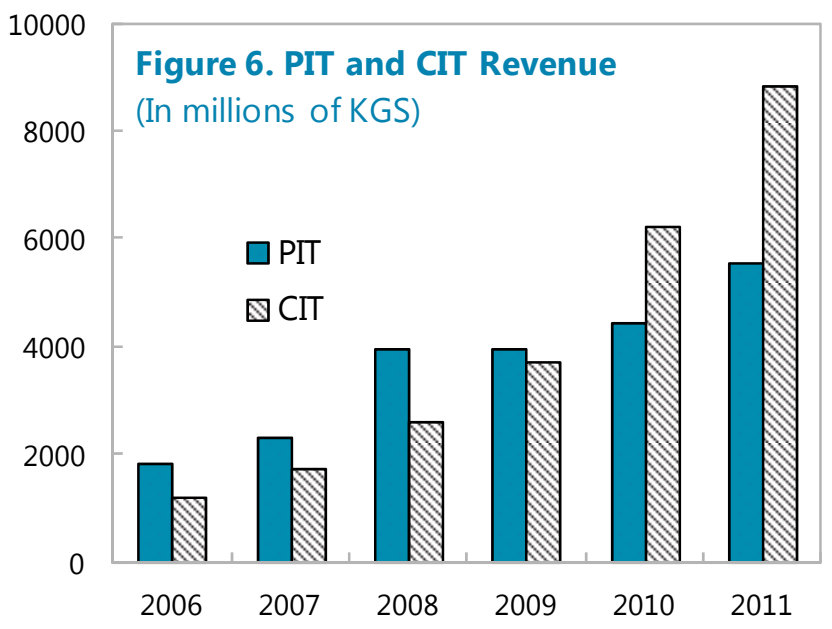

Sources: Kyrgyz authorities. the regular profit tax system.

\footnotetext{
${ }^{3}$ Under the simplified customs clearance regime, which was introduced in December 2004, most goods are assessed according to their weight (not their value).

${ }^{4}$ From 2009, following the agreement with Kyrgyz authorities, the Kumtor mining company has been paying 13 percent of its gross revenue. These proceeds are reflected as CIT in the government's budget. The company also pays social contributions to the Issyk-Kul Fund (1 percent of gross income), and the pollution tax (US\$310 thousand a year).
} 


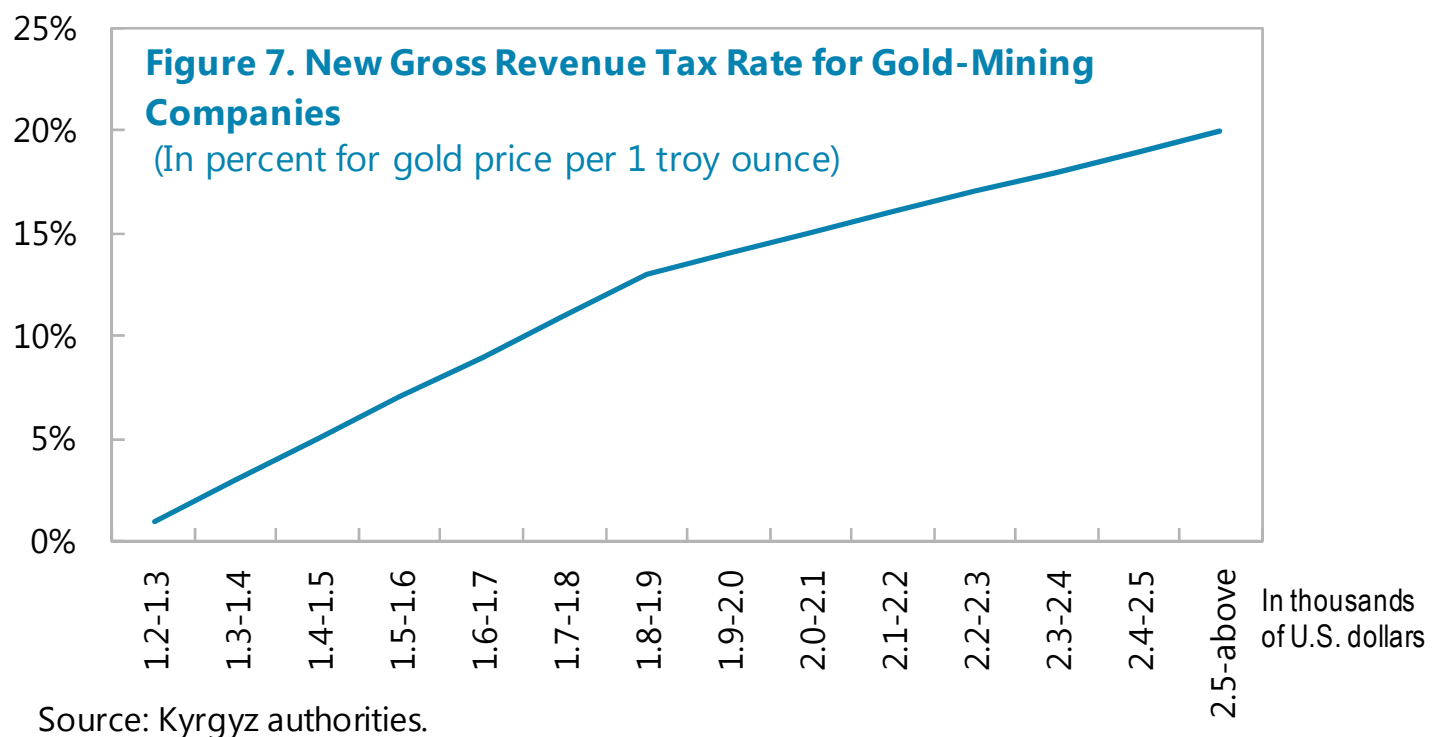

\section{The Tax Code contains six special regimes for certain activities, which replace VAT, CIT, and sales tax with a lump sum tax, exist in for certain activities.}

- The mandatory patent regime covers seven specific activities and replaces CIT, VAT, and turnover tax. Voluntary patents are available to individual taxpayers below the VAT threshold (KGS 4 million) and replace CIT and the turnover tax. With 125 eligible activities, this regime remains complex. Revenues from mandatory and voluntary patents are low at about 1 percent of total tax revenue. The current patent regimes unevenly distribute the tax burden among taxpayers below the VAT threshold and discourage taxpayers in the voluntary patent system from migrating to the regular system.

- The simplified single tax regime replaces CIT and turnover tax and is for taxpayers who are not registered for VAT. This regime yields negligible revenue ( 0.1 percent of total tax revenue).

- Under the contract-based tax, taxpayers enter into a contract for the payment of a fixed tax, which is calculated as the highest tax liability (CIT, VAT, and sales tax) in the preceding three years and increased by 25 percent. This regime can be very discretionary and open to abuse.

- Free Economic Zones (FEZs) are four areas free of taxes. Goods and services supplied from FEZs within the country are taxed in line with the general tax regime, while goods and services supplied to FEZs from other parts of the country are subject to VAT. No studies have been conducted to estimate tax expenditure (foregone tax revenue) as a result of setting up the FEZs.

- Under the high technologies park regime, residents develop information technology products and are free of CIT, VAT, and sales tax. PIT is paid at the rate of 5 percent. 


\section{Tax Incentives}

\section{Existing incentives}

\section{Numerous VAT exemptions are the main weakness of the VAT system in the Kyrgyz}

Republic. The following exempt activities are the most important to focus on: the agricultural sector, residential buildings, public utility services, medical activity, financial and insurance services, transportation services, infant food, natural gas, and imported fixed assets (capital goods). Recently, the authorities removed VAT exemptions on internet and roaming services.

\section{Most VAT exemptions aim to achieve social policy objectives but instead create complexity and erode the VAT base:}

- The main objective of VAT exemptions in the agricultural sector is to maintain lower prices for agricultural produce. However, with small farms below the VAT threshold constituting a major part of the agricultural sector, VAT exemptions may not result in lower prices. At the same time, larger firms, which are in the VAT system, do not provide needed revenue for the state budget.

- Exempt fixed assets (exceeding KGS 200,000) that businesses import for their own use present risks of revenue loss. These risks could materialize if fixed assets are imported for other use (selling the assets in the domestic market).

- VAT exemptions for residential buildings and public utilities and transportation services erode the tax base and are not well targeted to poor households.

\section{Other exemptions and the patent regime continue to weaken CIT collections. CIT} exemptions in the agricultural sector are the most substantial (given that the sector accounts for about 20 percent of GDP). In addition, firms that process agricultural produce are also exempted from CIT (except for goods subject to the excise tax). Other exemptions relate to FEZs, charitable organizations, interest income, and dividend income received from domestic activities. The low-yielding voluntary patent regime results in a large number of taxpayers to be outside of the CIT system.

\section{The authorities contemplate lowering the CIT rate for newly opened businesses in} remote regions. If implemented, the reductions would be temporary, for five years (2 percent until 2015, 4 percent until 2017, and 5 percent until 2019), and would be reflected in the Tax Code. The main rationale is to develop remote regions where income levels are low and labor migration is high. Given that lower CIT rates will apply to new businesses only, direct revenue loss is expected to be zero. However, some future revenue losses would still arise if businesses could have started even in the absence of lower tax rates. In addition, if incentives open new routes for evasion, their costs could increase significantly. For example, businesses could engage in "transfer pricing", that is, minimize their tax obligations by reporting profits in the remote regions where the tax rates are lower. The Tax Code allows the tax authorities to revise taxpayers' assessment of prices if the 
following transactions are not considered to be conducted at market prices: (i) between related parties, (ii) on barter transactions, and (iii) on external transactions.

\section{International experience review and pros and cons of incentives}

\section{Empirical studies and international experience suggest that tax incentives do not} appear to have sizable effects on investment in the long term. At the same time, fiscal costs from tax incentives can be substantial. The analysis of the effects of tax incentives in transition economies (OECD, 1995) showed that incentives were unlikely to spur FDI inflows. Another OECD study demonstrated the limitations of the effects of tax incentives on economic growth (OECD, 2010). In Brazil, tax incentives distorted the tax system, lowered revenue, and did not stimulate investment (Estache and Gaspar, 1995). Tax holidays in Malaysia could not promote investment in targeted activities (Boadway, Chua and Flatters, 1995). In Thailand, investment would have increased even in the absence of incentives because the rate of return was high enough (Halvorsen, 1995).

19. To decide whether incentives should be applied, the Kyrgyz government needs to have clear estimates of costs and benefits, which, however, are difficult to assess. Direct costs that are challenging to quantify include rent-seeking behavior and distortions to the economy. In addition, administrative costs from running regimes with tax incentives can take substantial resources. Indirect effects of incentives include crowding out other investment that could have generated more tax revenue. Revenue growth would only take place if tax incentives result in total investment growth, which would spur taxes on additional inputs and employment. The Kyrgyz authorities work toward boosting specific sectors or some areas of the country, including through introducing tax incentives. It should be noted, however, that aggregate investment is not likely to increase in this case. Instead, targeted sectors or areas may experience investment inflows relocated from other parts of the economy.

20. If the introduction of tax incentives is unavoidable, the Kyrgyz government needs to apply the principles of good tax policy. Transparency and predictability are essential for investors who make long-term investment decisions. Reflecting incentives in the tax law of the country is a better choice than introducing incentives as separate decrees or contracts with private firms because scope for corruption will be significantly lower. As mentioned above, incentives should be designed in a way that ensures robustness to tax evasion.

\section{Tax incentives can be granted in various forms with different cost-effective structures (Text Table 2).}

- Tax holidays relieve tax authorities of the administrative burden but are mostly attractive to short-term investment with unclear amounts of foregone revenue. In addition, tax holidays provide strong incentive for tax avoidance (through transfer pricing). Usually, a new administration chooses these temporary types of incentives to signal its readiness to improve the business environment. With the business environment improved, investment would stay even when tax incentives expire. In practice, however, reforms to make the business environment more friendly stall 
often but tax holidays or reduced tax rates last for many years being continuously renewed.

- Reduced CIT rates have mostly the same characteristics as tax holidays but on a smaller scale. The difference between tax holidays and reduced CIT rates can also be seen when analyzing the revenue cost, which is lower under the latter.

- Investment allowances and tax credits can be implemented in a transparent way and can be better targeted than tax holidays for promoting certain types of investment. However, these incentives can distort the choice of capital in favor of short-lived assets because a further allowance becomes available each time an asset is replaced.

- Accelerated depreciation is considered the least harmful among CIT associated incentives. Its disadvantages are largely similar to investment allowances and tax credits with the exception that this incentive does not distort in favor of short-lived assets.

- VAT exemptions are prone to abuse as businesses can redirect exempt assets to other recipients outside of the exempt area. In addition, given that VAT on zero-rated inputs is creditable, VAT exemptions may be of little benefit. Moreover, usually those who spend more get proportionally more benefits if VAT exemptions are in place.

- In case of export processing zones, revenue costs can be significant if profits are shifted to these zones. 
Text Table 2. Kyrgyz Republic: Assessment of Typical Tax Incentives

Advantages

\section{Tax Holidays}

Simple to administer.

Certainty for the investor of tax environment

Can provide an immediate and large benefit to start-ups who are profitable early in their life-cycle

Allows taxpayers to avoid contact with tax administration (which is important if administration is perceived as corrupt or inefficient).

\section{Lower CIT rates}

Simple to administer.

Does not have end-point problem of tax holidays.

Provides strong signal of government's welcoming stance towards foreign investment.

Revenue costs are lower than under tax holidays.

\section{Tax Credits and Investment Allowances}

The tax benefit is given upfront rather than over several years.

Revenue costs are more transparent (easy to measure).

Can be targeted towards specific kinds of

investment or to promote investment in long-lived

assets.

On average, results in less revenue leakage than

holidays by targeting current capital outlays.

\section{Accelerated Depreciation}

Permits an increase in the rate of annual write-off or provision of an initial allowance after which the value less the allowance is written off at standard rates.

Does not necessarily discriminate in favor of shortlived assets.

\section{Exemptions from Indirect Taxes (VAT, excises, etc)}

Allows taxpayers to avoid contact with tax administration (which is important if administration is perceived as corrupt or inefficient).

\section{Export Processing Zones}

Allows taxpayers to avoid contact with tax administration (which is important if administration is perceived as corrupt or inefficient).
Does not attract firms with large start-up costs and benefits most short-run projects

Difficult to abolish without creating competitive distortions between new and existing firms.

High cost since all profits are exempted; the greatest benefit is to the high-return firms that are likely to have invested even without the incentive.

Provides incentive for transfer pricing (intracountry and international)

Revenue cost is difficult to assess unless tax returns are filed and assessed (in which case administration costs are incurred without raising revenues).

Finite period of tax holidays creates perverse effects since the value of the incentive diminishes as the holiday approaches expiration).

May be costly from a revenue perspective

May act as a weaker incentive since benefits accrue over life-cycle of project rather than Largest benefits go to high-return firms that are likely to have invested even without incentive.

If lower rates are for some sectors or areas of the country, invites tax avoidance through hightax enterprises shifting profits to low-tax ones via transfer pricing (intracountry and Acts as windfall to existing investments.

Unlike specific benefits, may not be tax spared by home country tax authorities.

A given level of credit favors short versus long-lived assets--if a credit is payable on each asset purchase.

Greater administrative burden--the scope for fraudulent claims is higher if credits are not applicable to all investment.

Offers no immediate benefit to loss-making firms and favors existing companies over start-ups (since the former are more likely to have profits to apply credit against).

Discriminates against activities that are intensive in uses of capital but that do not benefit from credits.

To some extent similar to tax credits and initial allowances but typically provides a smaller benefit (although depends on the degree of acceleration).

Prone to abuse as qualified purchases can easily be diverted to buyers not intended to receive the incentives.

Zero rating inputs under the VAT make little difference the firm making the purchase, since VAT on such purchases is (or should be) creditable.

Leakage of untaxed goods into domestic market can be rampant, either because of defects in the security system or corruption. 


\section{Tax Policy Reform Options}

22. Although tax revenue in the Kyrgyz Republic is already high compared with countries with similar income levels, efforts are still needed in the medium term to further increase revenue. In the short to medium term, existing tax policy measures and ongoing tax administration reforms are expected to improve the efficiency of the tax system and generate the needed revenue. However, these efforts may be undermined by existing and new tax incentives. Further down the road, more significant tax policy measures, in addition to administrative improvements, are needed to support the government's development agenda. The Kyrgyz government needs to safeguard economic and social stability, if higher growth is to be sustained. Moreover, tax policy measures could reduce distortions and administrative costs.

23. Eliminating some VAT exemptions should be a priority for the medium term to achieve the broadest possible VAT base. Given that VAT exemptions are not guaranteed to be reflected in the final price of the product, VAT exemptions should not be applied for the purposes of social benefits. A more effective resource reallocation policy would be to collect full VAT and use the revenue for targeted social assistance programs. Without being effective in reducing the tax burden on those in need, VAT exemptions weaken the VAT chain of enforcement. As an important step toward broadening the VAT base, the government has recently eliminated VAT exemptions on roaming and internet connectivity. The agricultural sector, public utility services, transport services, residential buildings, and fixed assets would also bring additional revenue if no VAT exemptions apply (or exemption thresholds are raised, e.g. in case of fixed assets). Improving the VAT refund system would also be needed. With a weak refund mechanism, VAT would be, in principle, a cascading tax. The authorities need to conduct, perhaps with technical assistance from the IMF, a broad review of VAT exemptions. This review would provide a detailed assessment of the cost of these exemptions, which would help the authorities take steps in removing the exemptions.

24. The pros and cons need to be assessed carefully before introducing tax incentives; where incentives are already in place, close monitoring or removal is needed. The preferred instruments, if pressure to introduce tax incentives does not subside, include accelerated depreciation or investment allowances and tax credits. Temporarily lower CIT rates for newly created businesses in remote regions does not necessarily stimulate additional investment in those regions, but if introduced, monitoring of their implementation will be important. In addition, the tax authorities will need to monitor transfer pricing in the domestic market to ensure that prices are not misstated in order to shift the source of profit to remote regions where lower CIT rates are in effect. This monitoring, however, requires specialized skills. In this regard, the tax authorities will need to strengthen their capacity to deal with transfer pricing issues. Moreover, enforcing tax compliance of existing businesses would help ensure that new routes for tax evasion are not opened and no revenue costs follow the introduction of this incentive. To broaden the tax base, CIT exemptions for agricultural producers could be eliminated. The cost of these CIT exemptions could also be assessed under the review of exemptions mentioned above.

25. Additional medium-term measures that could strengthen revenue mobilization and at the same time improve the efficiency and equity of the tax system include: 
- Overhauling the patent system. This would distribute the tax burden among taxpayers below the VAT threshold more evenly. A new patent system could consist of a simplified patent system with just few categories for micro-businesses (e.g. with turnover of less than US\$10,000) and a presumptive tax regime based on turnover for businesses between US $\$ 10,000$ and the VAT threshold. Presumptive tax regimes could also be based on gross profit and physical characteristics.

- Phasing out the contract-based regime. This would minimize the risk of corruption that is often present in administering such kind of tax regimes. The contract-based regime can be a temporary solution to raising revenues but not a permanent one. Instead, a system that would consist of assessing the turnover of businesses and applying a margin ratio to appreciate their benefit should be introduced.

- Switching completely from the weight-based to a price-based valuation system. This would allow to tax a major part of goods imported from China and re-exported to Kazakhstan. In addition, the price-based valuation system would result in a substantial increase in VAT revenue. To avoid undervaluation at customs, reference pricing methods could be applied.

- Raising excise rates. Given that demand for these goods is relatively inelastic and the revenue base is wide, the rate increase would bring immediate growth in revenue. In addition to being a productive source of revenue, excises can also discourage excessive consumption of the relevant goods. Periodic adjustments for specific excises would be needed to ensure the proceeds are not eroded by inflation.

\section{Phasing-out the turnover (sales) tax in the medium term would remove distortions. At} the same time, the authorities will need to find an alternative source of revenue that would compensate for the revenue loss stemming from eliminating this tax. A VAT increase would be the most effective solution. A one percentage point increase in the VAT rate is estimated to bring additional KGS 1.5 billion in revenue. Therefore, to offset the loss from the removed turnover tax, the VAT rate would need to be raised by three percentage points. An increase in the VAT rate would not result in lower investment or trade because VAT does not fall on businesses. In addition, under the VAT regime, taxes on inputs are credited against taxes on output. Another important feature of VAT is that it matters little that a country has a higher VAT than its neighboring country because under the "destination principle" VAT paid on a good is determined by the rate levied in the country of the good's final sale with revenue accruing to that country.

\section{To increase transparency, the authorities need to introduce a tax expenditure}

statement and include it in the budget. No study has been conducted to thoroughly examine the current tax incentives and determine the revenue cost. Also, measuring the revenue cost of the FEZs and carrying out a cost-benefit analysis of the system would help taking a decision of whether to continue maintaining the FEZs. Assessing incentives' costs and publishing them as a tax expenditure statement would strengthen monitoring and transparency. Moreover, this would effectively inform policy formulation. 


\section{References}

Boadway, R., D. Chua, and F. Flatters, 1995, "Investment Incentives and the Corporate Income Tax in Malaysia," in A. Shah, Fiscal Incentives for Investment and Innovation, 341-73 (New York: Oxford University Press).

Botman, Dennis, Hagemann, Robert, and Ly, Sodeth, 2006, "Investment Incentives in Cambodia: A Comparison with Neighboring Countries", Selected Issues Paper, IMF, Country Report No. 06/265 (Washington: International Monetary Fund).

Chalk, Nigel, 2001, "Tax Incentives in the Philippines: A Regional Perspective," IMF Working Paper WP/01/182 (Washington: International Monetary Fund).

Dobrescu, Gabriela, Nelmes, John, and Yu Jiangyan, 2011, "Nepal's Tax Regime", Selected Issues Paper, IMF, Country Report No. 11/319 (Washington: International Monetary Fund).

Estache, A. and Gaspar V., 1995, "Why Tax Incentives do not Promote Investment in Brazil," in A. Shah, Fiscal Incentives for Investment and Innovation, 309-40 (New York: Oxford University Press).

Halvorsen, Robert, 1995, "Fiscal Incentives for Investment in Thailand," in A. Shah, Fiscal Incentives for Investment and Innovation, 399-436 (New York: Oxford University Press).

Klemm, Alexander, 2009, "Causes, Benefits, and Risks of Business Tax Incentives", IMF Working Paper WP/09/21 (Washington: International Monetary Fund).

Harrison, Graham, Masters, Andrew, and Fenochietto, Ricardo, 2009, "Kyrgyz Republic: Securing Tax Revenues during the Economic Downturn", IMF TA Report (Washington: International Monetary Fund).

Organization for Economic Cooperation and Development, 1995, Taxation and Foreign Direct Investment: the Experience of the Economies in Transition (Paris: Organization for Economic Cooperation and Development).

2010, Tax Policy Reform and Economic Growth, Tax Policy Studies, No. 20 (Paris: Organization for Economic Cooperation and Development).

Rota-Graziosi, Gregoire, 2011, “Kyrgyz Republic: Notes on Tax Policy”, IMF (Washington: International Monetary Fund). 
Zee, Howell H., Stotsky, Janet G., and Ley Eduardo, 2002, "Tax Incentives for Business Investment: A Primer for Policymakers in Developing Countries," World Development, Vol. 30, No. 9, 1497-1516. 


\section{TRANSMISSION CHANNELS OF MONETARY POLICY IN THE KYRGYZ REPUBLIC ${ }^{1}$}

Monetary policy in the Kyrgyz Republic faces challenges with respect to formulation and efficacy given the low monetization (M2 to GDP of 32 percent at end-2012), the shallow financial system (bank assets at 30 of GDP at the end-2012), high dollarization (52 percent at the end 2012) and a predominantly cash-based economy (currency in circulation at 56 percent of broad money at the end of 2012).

\section{A. Background}

\section{While monetary policy is considered a powerful tool in developed economies, a} number of questions about the efficacy of monetary policy arise in low income countries (LICs). Empirical research suggests that the traditional transmission channels are impaired in LICs, mainly because of an underdeveloped financial system, high dollarization, and a weak institutional framework. Previous research on the Kyrgyz Republic suggests that the link between monetary aggregates and inflation is broken rather often, in particular during the 2001 to 2008 period. $^{2}$ This still continues to be the case (Figure 1), and aggregates do not respond properly to National Bank of the Kyrgyz Republic (NBKR) actions. An exception

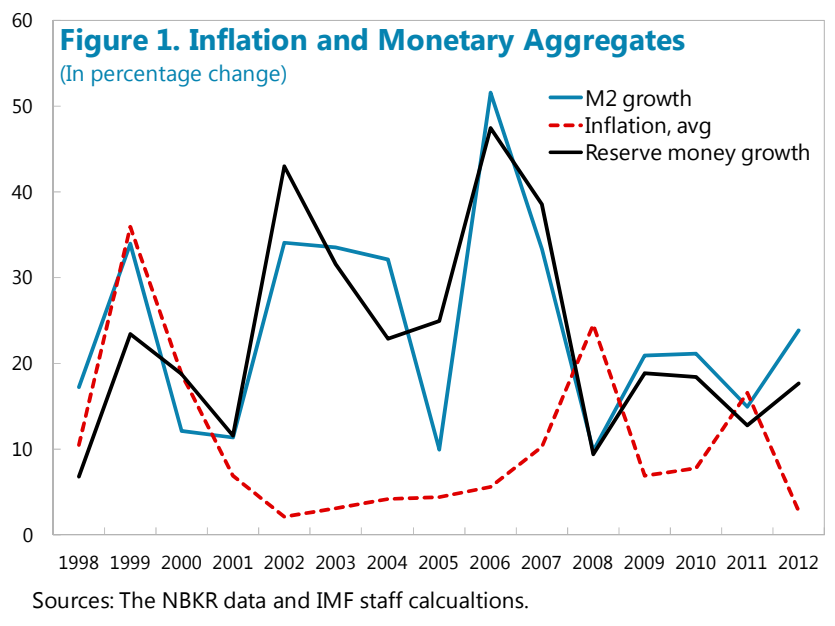
is the exchange rate channel. ${ }^{3}$

\section{B. Current Monetary Policy Framework}

2. The main objective of the NBKR is to maintain price stability. Subordinated objectives are to support the purchasing power of the national currency, and safety and reliability of the banking and payment system. The NBKR uses a monetary targeting framework to ensure price stability, with M2 as intermediate target and reserve money as an operational target. The NBKR focuses on the elimination of excess liquidity from the system. The track record in achieving targets has been mixed, as forecasted and actual inflation, as well as targeted and actual growth rates of monetary aggregates deviate frequently (Text Table 1).

\footnotetext{
${ }^{1}$ Prepared by Dragana Ostojic.

${ }^{2}$ IMF (2008).

${ }^{3}$ Isakova (2008).
} 
Text Table 1. Kyrgyz Republic: Inflation and Monetary Aggregates Targets vs Actuals

\begin{tabular}{|c|c|c|c|c|c|c|c|c|c|c|c|c|c|c|}
\hline & & 2000 & 2001 & 2002 & 2003 & 2004 & 2005 & 2006 & 2007 & 2008 & 2009 & 2010 & 2011 & 2012 \\
\hline \multirow{2}{*}{ Inflation (in percent) } & Target & 15 & $10-12$ & $6-8$ & $4-5$ & 4,5 & $4.7^{*}$ & 5.7 & $9^{*}$ & $12-15$ & 7.5 * & $7.5-9.5$ & $8.0-10.0$ & $7.0-9.0$ \\
\hline & Actual & 9.6 & 3.7 & 2.3 & 5.6 & 2.8 & 4.9 & 5.1 & 20.1 & 20.0 & 0.0 & 19.2 & 5.7 & 7.5 \\
\hline \multirow{2}{*}{ Reserve money } & Target & & & 1.9 & 1.9 & 1.4 & 16.2 & 7.2 & 19.5 & 18.3 & 13.3 & 23.9 & 16.4 & 16.0 \\
\hline & Actual & & & 42.9 & 31.6 & 22.9 & 24.9 & 47.4 & 38.5 & 11.3 & 16.8 & 18.4 & 12.8 & 17.7 \\
\hline \multirow{2}{*}{ Board Money } & Target & & & 7.6 & 6.9 & 5.4 & 16.2 & 17.9 & 20.3 & 17.3 & 23.3 & 19.3 & 15.7 & 18.3 \\
\hline & Actual & & & 34.1 & 33.5 & 32.0 & 9.9 & 51.6 & 33.3 & 12.6 & 17.9 & 21.1 & 14.9 & 23.8 \\
\hline
\end{tabular}

* Revised mid-year

Sources: NBKR and IMF staff calcualtions.

\section{Base money growth is primarily driven by net foreign assets (NFA), while the impact of} changes in net domestic assets (NDA) is small (Figure 2). Reserve money growth in 2012 was 17.7 percent, of which NFA contributed 28.7 percent, while NDA contributed -11.0 percent. NFA accumulation is driven by inflows of grants and loans (more than US\$400 million in 2012), and a gradual build up of gold reserves. Despite of the buildup of NFA, net international reserves remained constant at four months of imports, as the economy is expanding. Liquidity in the system has been growing rapidly, and excess reserves account for 40 percent of total reserves on average. Historically, the reasons for increased liquidity were unsterilized interventions, but during the last few years the NBKR has intervened in the foreign exchange market minimally, just to eliminate excess volatility (net interventions in 2012 were about US\$37 million). The nominal exchange rate has depreciated gradually, while the real effective exchange rate has been appreciating due to high inflation, improved terms of trade (increasing gold prices), and NFA accumulation.

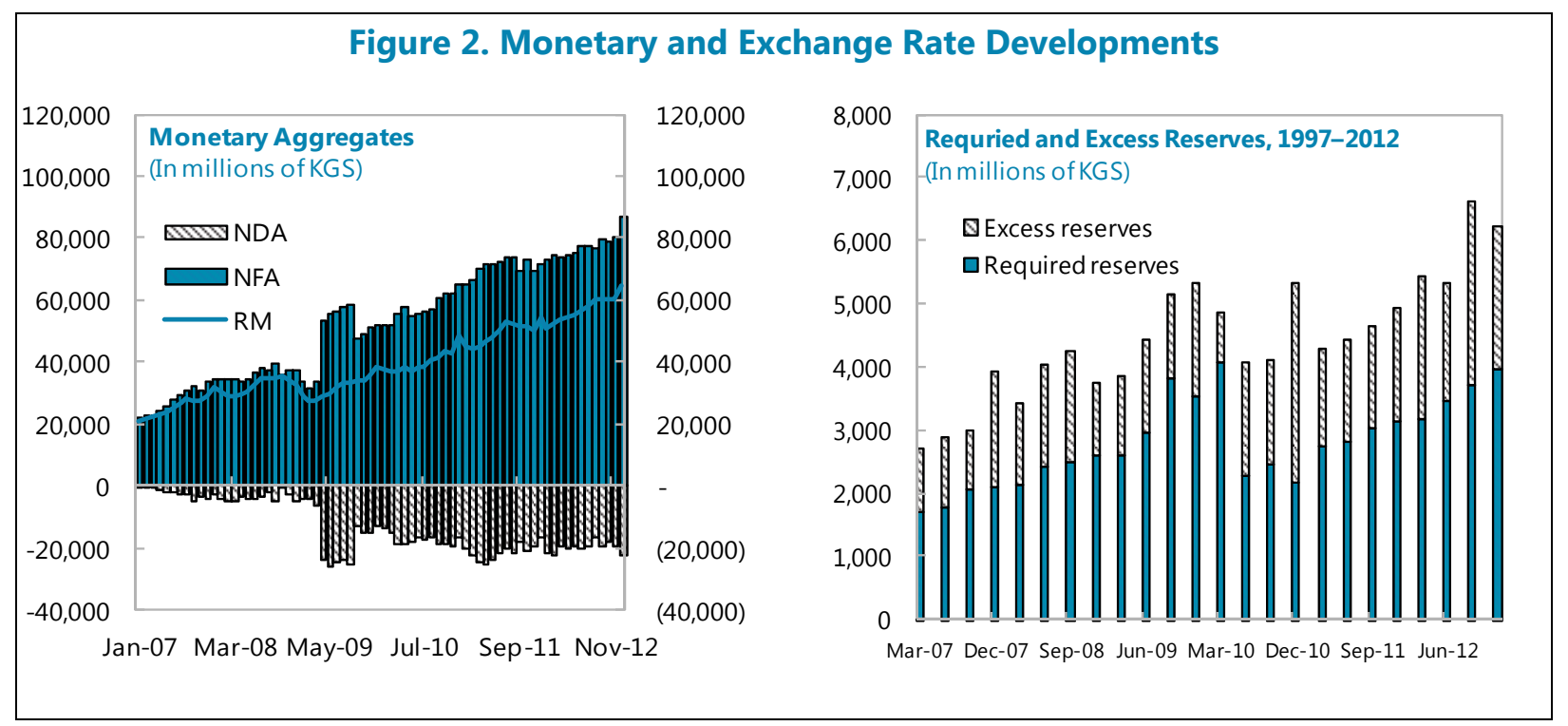



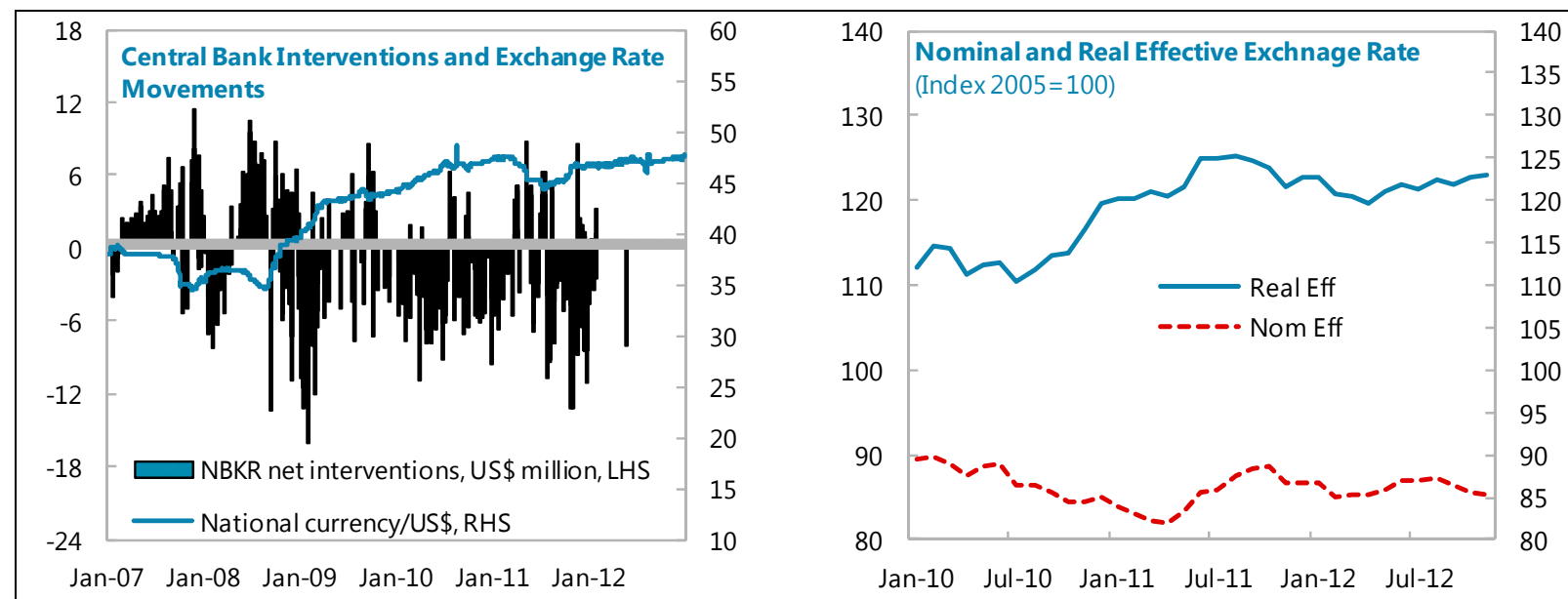

Source: The NBKR data.

\section{Monetization of the economy remains limited given the shallow financial system.}

Despite the sizeable increase over the last seven years, monetization is still low with M2 to GDP at 32 percent at the end-2012, and the financial system is still shallow with banking sector assets at 29.9 percent of GDP (Text Table 2). This is common across the CIS region and is in line with the average for LICs. Deposits and credit to the private sector are below the LIC average. The dollarization of loans and deposits is on a declining trend, but remains high despite the stable exchange rate. Inflation volatility is decreasing, but remains high and thereby fosters dollarization. Moreover, the high share of currency outside banks in $\mathrm{M} 2$ (56 percent) suggests a preference for cash transactions over transaction via the banking system (Figure 3). This may be due to political instability, low confidence in the banking system that still has problem banks, and historic cultural preferences for holding cash.
Figure 3. Reserve and Broad Money (December 2012)
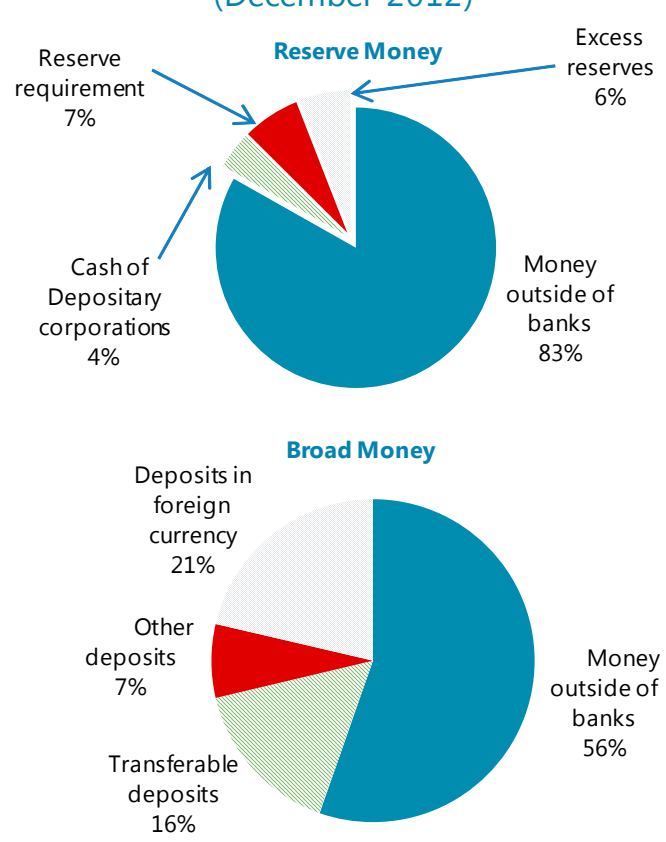

Source: The NBKR data. 
Text Table 2. Kyrgyz Republic: Comparison of Selected Banking Indicators

\begin{tabular}{|c|c|c|c|c|c|c|c|c|c|}
\hline & & Kyrgyzstan & & CCA Average & & & $\begin{array}{l}\text { Low } \\
\text { Income }\end{array}$ & $\begin{array}{l}\text { Middle } \\
\text { Income }\end{array}$ & $\begin{array}{l}\text { High } \\
\text { Income }\end{array}$ \\
\hline & 2005 & 2010 & 2012 & 2005 & 2010 & 2012 & 2009 & 2009 & 2009 \\
\hline Currency outside banks / M2 & 61.4 & 60.0 & 55.9 & 62.4 & 48.7 & 43.9 & & & \\
\hline M2/GDP & 21.1 & 31.4 & 32.4 & 13.4 & 23.0 & 26.4 & & & \\
\hline Banking sector total assets/GDP & 23.0 & 29.4 & 29.9 & 29.3 & 36.7 & 44.7 & 32.0 & 50.7 & 128.9 \\
\hline Banking sector total deposits/GDP & 8.2 & 12.6 & 14.4 & 10.6 & 15.6 & 19.4 & 26.3 & 51.3 & 110.5 \\
\hline Bank Credit to private sector/GDP & 7.8 & 12.5 & 13.8 & 12.4 & 17.4 & 20.7 & 19.6 & 40.6 & 117.3 \\
\hline Lending-deposit spread, domestic currency & 16.5 & 23.3 & 24.6 & 11.0 & 12.5 & 14.6 & & & \\
\hline Lending-deposit spread, foreign currency & 13.5 & 17.6 & 18.2 & 10.8 & 10.5 & 13.2 & & & \\
\hline Dollarization of deposits & 72.2 & 52.9 & 51.9 & 63.1 & 51.1 & 41.4 & & & \\
\hline Dollarization of loans & 64.8 & 55.7 & 47.8 & 66.8 & 55.0 & 55.9 & & & \\
\hline Average Inflation & 4.3 & 7.8 & 2.8 & 7.3 & 6.9 & 4.0 & & & \\
\hline Average real deposit rate, national currency & 1.1 & -2.4 & 3.3 & 3.8 & 2.4 & 3.9 & & & \\
\hline Policy rate & 4.1 & 5.5 & 2.6 & 5.1 & 5.2 & 4.2 & & & \\
\hline
\end{tabular}

Sources: Kyrgyz authorities, A Database on Financial Development and Structure, and IMF staff calculations.

\section{The NBKR uses a standard set of monetary instruments to achieve its targets:}

- Open market operations, (OMO) are conducted mainly with NBKR notes and repo/reverse repo operations on government securities in the NBKR's portfolio. The volume of operations with NBKR notes and repos has been increasing steadily over the last few years (Figure 4). However, this was not sufficient to mop up excess liquidity in the system. The amount offered at auctions varies substantially, and interest rates may not be attractive for banks. Auctions are held weekly

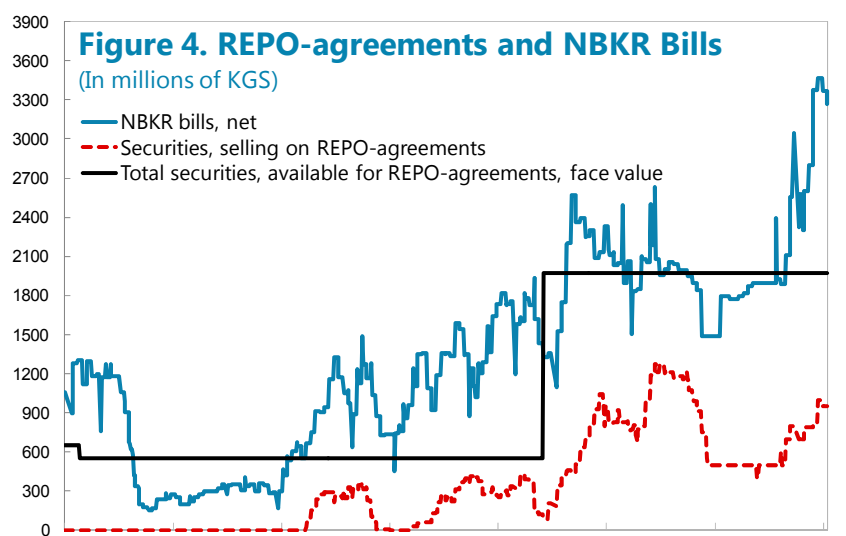

31-Dec-09 12-Jun-10 22-Nov-10 04-May-11 14-Oct-11 25-Mar-12 04-Sep-12 14-Feb-13 Source: The NBKR data.

(different days for repos, NBKR notes and T-bills) and mainly mop up the structural liquidity (long term assets matched by a stable long term funding), but there is no fine tuning at this time. There are no OMOs in the secondary market at this time.

- Operations in the foreign exchange market, include direct interventions and swaps.

The use of both instruments has diminished as the NBKR is trying to maintain a flexible exchange rate system and safeguard foreign reserves.

- The policy (discount) rate's use as an instrument is ambiguous because the mechanism of setting the policy rate and what the NBKR is trying to impact are not clear. According to the bylaws, the

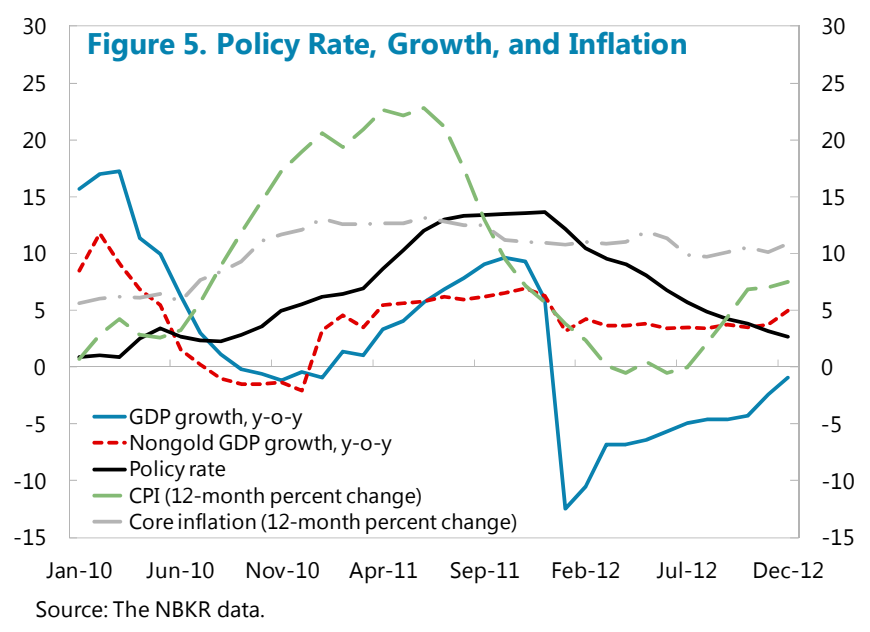


NBKR discount rate is linked to the average yield of the last four auctions of 28 day NBKR notes. However, it is not clear how the NBKR determines the cut-off rate for individual auctions of its notes which consequently affect the discount rate.

Furthermore, the discount rate is not used for NBKR credit operations and primarily serves as a benchmark rate for T-bills. Given this ambiguity about setting the policy rate, political pressures may therefore affect the level of the policy rate.

- Reserve requirements are applied on som and foreign currency deposits. The current rate is 9 percent for both.

- Other. The NBKR has rediscount facilities and a deposit facility in its portfolio of instruments, but most of them are rarely used.

\section{While legislation stipulates a high degree of de jure independence of the NBKR,} de facto independence is hampered by frequent government statements and judicial actions.

Table 3 presents findings of a study by Arnone et al. (2007) that assesses central bank independence based on analyses of legislation. The Kyrgyz Republic and the CCA region rank relatively high. However, the difference between de jure and de facto independence is very often substantial, as good legislation does not translate into good practice/implementation. Government initiatives to subsidize lending and interference with interest rate policy undermine the independence of the NBKR. Furthermore, under the Kyrgyz legal system, legal "codes" supersede "laws" in case of conflicts between codes and laws. For example, the Civil Procedure code supersedes the laws governing banking resolution. Consequently, rulings of the commercial court over the NBKR's decisions (for example the recent ruling of the Inter District Court to extend the forbearance period for Zalkar bank), contrary to the NBKR's legislation, weaken de facto independence. These actions send signals to the public that the NBKR's policies and decisions can be influenced by the government.

Text Table 3. Kyrgyz Republic: Comparison of de jure Central Bank Independence

\begin{tabular}{lrrr}
\hline & Overall & Political & Economic \\
\hline Kyrgyzstan & 0.88 & 1.00 & 0.75 \\
CCA average & 0.74 & 0.78 & 0.71 \\
LIC & 0.33 & & \\
Emerging & 0.60 & & \\
Advanced & 0.96 & & \\
\hline
\end{tabular}

* Higher score means higher indepedence.

Sources: Arnone et al. (2007); Mishra et al. (2010). 


\section{Transmission Channels of Monetary Policy}

7. Understanding the monetary transmission mechanism enables a central bank to impact economic activity and inflation through its monetary policy decisions. Figure 6 presents a standardized framework for monetary policy and its transmission channels. ${ }^{4}$

Figure 6. Transmission Channels of Monetary Policy

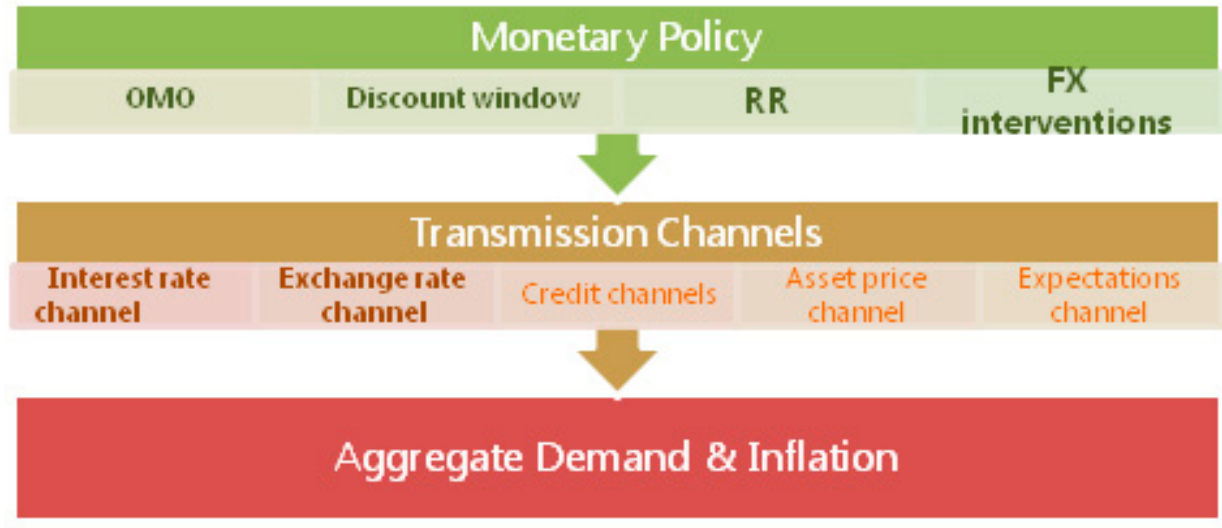

8. The interest rate channel is impaired, hampering the effectiveness of monetary policy in the Kyrgyz Republic. NBKR research finds that interest rates have almost no explanatory power on the behavior of monetary aggregates. ${ }^{5}$ Similarly, Isakova (2008) finds that "a one-percent increase in the repo rate in the Kyrgyz Republic will lead to an increase in CPI inflation of less than 0.03 percent, and this effect dies out after five month". This result is counterintuitive and confirms a broken relationship. Our research finds that a one percent increase in the policy rate will decrease inflation by 0.013 and the effect dies out after one month (estimated over the period December, 2001-December, 2012).

\section{The policy rate does not have a strong impact on other interest rates, except the} interbank rate. The interbank rate mirrors the movements of the policy rate (Figure 7). Moreover, "an increase in the policy rate by 1 percent will lead to an increase in interbank rates by 0.99 percent". ${ }^{6}$ However, our research indicate that the policy rate has a lower pass-through to the interbank rate, and the impact is changing over the time. ${ }^{7}$ This is expected as interbank market became more developed and active over the time. In addition, large swings in policy rates are not reflected either in deposit or lending rates (Figure 7). Our research suggest that an increase in the

\footnotetext{
${ }^{4}$ The asset price channel and expectations channels are difficult to analyze in a low-income country context, where equity markets are not developed, and there are limited data on the real estate market. Furthermore, investors may not be sophisticated enough to reallocate assets based on monetary policy signals.

${ }^{5}$ IMF (2007).

${ }^{6}$ Isakova

${ }^{7}$ Using weekly data, the pass through from the policy rate to the interbank rate is 0.29 percent for the period 1998-2012; it increases to 0.54 percent for the period after 2002, and to 0.60 percent for the period 2004-12. However, if we only analyze the period after 2007 the interbank rate overshoots, i.e. an increase of the policy rate of 1 percent results in an increase in the interbank rate of 1.05 .
} 
policy rate by 1 percent results in a decrease of deposit rates by 0.16 percent, while the impact on lending rates is not statistically significant.

10. The exchange rate is closely correlated with inflation, as in many other developing and highly dollarized economies. Given that remittances account for about 30 percent of GDP, and imports account for more than 60 percent of GDP any movements in the exchange rate can have a significant effect on inflation. ${ }^{8}$ Isakova finds that a 1 percent change in the nominal exchange rate will lead to 12 percent change in the CPI after two-three months. The findings of our research indicate a stronger pass through after a month about 19.6 percent. When controlling for international food prices, the pass through is somewhat higher i.e. about 21.3 percent.

\section{Credit channels, bank and balance sheet channels, tend to be impaired if the interest} rate channel is not working. If these channels are not working properly, the central bank may not be able to control the quantity of credit offered, because banks can choose to hold reserves or invest in T-bills rather than adjust the amount they lend to the economy.

\section{Barriers to Effective Monetary Policy}

12. The necessary conditions for successful monetary targeting are not fully in place, which explains why the NBKR is missing its targets. First, there is no strong or stable relationship between monetary aggregates and inflation. The second condition concerns the link between monetary instruments and the chosen monetary aggregate, which is weak in the Kyrgyz Republic due to characteristics of the banking and monetary system. Improvements in monetary operations, in particular OMOs could be a way out. Third, for a monetary aggregate to be a feasible policy target, reliable data are required. While monetary statistics are satisfactory, inflation statistics need to be improved (producer, export and import price indices). Another complicating factor is the amount of foreign currency in circulation.

13. The current setting further complicates targeting of monetary aggregates guided by a liquidity forecasting exercise. If the liquidity forecasts for government needs are done properly (functioning treasury), then it is easier for the NBKR to get its liquidity forecasts right and withdraw excess liquidity in a timely fashion. Furthermore, the effective sterilization of foreign currency inflows is usually problematic for the monetary authorities, in particular in countries with high remittances and/or capital inflows, and leads to the monetary authorities missing their targets. Also, money demand increases with stabilization and an improvement in the overall economic environment, which may result in high growth rates of monetary aggregates that do not necessarily transfer into inflation.

\section{The main impediments for transmission of policy rates into the real economy and inflation in Kyrgyz Republic are:}

\footnotetext{
${ }^{8}$ In addition to high dollarization of deposits and loans, foreign currency in circulation may be high. While there is no official survey on foreign currency in circulation or recent data, Feige (2003) estimates that in 2001 average foreign currency holdings per capita was US $\$ 20$, and it made about 48 percent of total cash held.
} 
- Low levels of monetization and financial intermediation, coupled with high dollarization and preferences for cash. The NBKR's OMOs can only affect a very small portion of reserve money (Figure 3). The high level of foreign currency denominated loans may also impede the interest rate channel, as borrowers can easily switch from loans in national currency to loans in foreign currency.

- In addition to size, the structure of the Kyrgyz banking sector is preventing the transmission of NBKR actions. Persistently high lending-deposits rate spreads (24 percent in som and 18 percent in foreign currency) suggest that competition is low, which effectively constitutes a barrier (see Box 1 ). In such an environment, banks can easily substitute high excess reserves with other investments. For example, tightening/easing monetary policy does not necessarily result in a reduction/increase of supply of bank credit. Government owned banks account for 22 percent of banking sector assets and 17 percent of total deposits in the Kyrgyz Republic. Even though not too high, Box 1 highlights that the presence of government banks impedes monetary transmission.

- Asymmetric information about clients and a poor institutional environment increase the cost of doing business for banks, so they choose not to lend and consequently not to transmit monetary policy actions. The cost of conducting due diligence of clients in the Kyrgyz Republic is high as there is no comprehensive credit registry.

Furthermore, recovery of clients' collateral is slow and costly.

- Lending that is not based on market decisions or subject to any other form of financial repression. Government involvement in the allocation of credit to sectors and or initiatives to subsidize interest rates is preventing banks from passing the effects of NBKR decisions to borrowers. At the same, such initiatives are causing distortions between borrowers, as some get benefits of preferential treatment while others (even though in the same sector) do not. The recent initiative to subsidize agriculture sector loans is an example of creating a barrier to effective monetary policy.

- The nonbank financial sector is becoming increasingly important, and directly competes with banks. The presence of micro-finance institutions and specialized money lenders is also reducing the importance of banks and credit channels.

- Underdeveloped interbank, money and stock market. The foreign exchange interbank market is relatively active in the Kyrgyz Republic (with an average daily turnover of US\$4 million), while the interbank credit market is sluggish (total amount traded in 2012 is KGS 1.3 billion). The volume of transactions in the secondary market is low with overall capitalization of less than 2 percent of GDP. The outstanding stock of T-bills and T-bonds is about 3.2 percent of GDP.

- Informal sector presence may be high, as suggested by high currency in circulation. 


\section{Box 1. Kyrgyz Republic: General Barriers to Effective Monetary Policy}

The literature finds the following as main barriers to effective monetary policy:

- High dollarization may reduce the impact that changes in the policy rate have on banks' interest rates in local currency, as borrowers can switch to the other currency.

- Financial shallowness tends to lead to higher excess liquidity in banks, discourages the development of an active interbank-market, and reduces effectiveness of the first part of the transmission channel.

- Lack of exchange rate flexibility hampers the effectiveness of the interest rate channel, as the exchange rate becomes a more important policy tool than the interest rate, signals about monetary policy to markets are not clear, and monetary policy is less independent in general.

- Financial repression defined as any restriction in the market setting mechanism of interest rates. These usually include control of interest rates, either in the form of a floor or ceiling, or subsidized interest rates for certain sectors or state owned enterprises. Similarly, directed lending from the government via banks to certain sectors also diminishes the role of monetary policy. This prevents policy rates to be properly transmitted into deposits and lending rates, and distorts the allocation of resources to the most profitable projects.

- The extent of central bank independence affects the scope for monetary or other policies as well as signaling about policies.

- Low competition in the banking sector, in particular the role of government-owned banks. In a low-competition environment banks do not pass the policy rate into market rates and maintain high margins even though the cost of funding is changing. Government banks are usually more engaged into directed credit and subsidized interest rates and less concerned about outcomes of their operations as they rely on government for the subsidy/covering its losses. Furthermore, the size of the non-bank financial sector is important, as this sector directly competes with the banks.

- Health of the financial system as weak banks may respond to the central bank's injection of liquidity or lower rates by building up liquidity and increasing margins. Holding the loans on the balance sheet may crowd out new lending. The quality of supervision is important to disclose information about classifications of loans.

- Underdeveloped interbank, money and stock market. A low volume of transaction between banks may be due to a low level of trust among banks as information about banks health may not be fully transparent. This usually impedes the operation of the interest rate channel. The lack of, or the underdevelopment of the stock market, usually impedes the asset channel and results in difficulties in pricing physical capital. In addition, if the secondary market for government securities is not developed, the central bank is limited to conduct open market operations only in the primary market and with the commercial banking system.

- Quality of institutional and regulatory environment in banking, as well as in the business sector. Regulations in the banking sector, as well as regulations for the environment in which banks operate are also important for the efficacy of monetary policy. Accounting standards, property rights, the legal system, bankruptcy and collateral regulations, etc affect the size of the financial sector and the cost of its operation. If rules are less certain, banks will be less prone to lend and transmit the impact of monetary policy decisions. Similarly, the quality of banking supervision, existence of a credit registry, deposit insurance schemes, etc., are important in building confidence in banks and increasing the amount of transactions done via the financial system.

- An informal sector, which is usually hard to estimate, may also hinder the effects of monetary policy. The informal sector usually operates with cash and any monetary policy decision does not affect it. If the informal sector is proportionally high, monetary policy will be less able to affect aggregate demand.

- Fiscal dominance implies that the management of government debt is more important, so interest rates are set accordingly. In addition, government financing may be crowding out the private sector. 
- Alternative sources of financing. With high holdings of cash and high inflows of remittances, individuals and businesses may not depend on banks to finance their transactions (business, real estate investments, consumption), as they have alternative sources of finance.

\section{E. Concluding Remarks and Recommendations}

15. Notwithstanding its limited means to impact economic activity and inflation, the NBKR should maintain and refine its current monetary policy framework. The monetary targeting framework is adequate under current circumstances, and the NBKR should look into ways to improve it. The mechanism for setting the policy rate (discount rate) and its role should be reexamined. In order to increase the effectiveness of the interest rate and credit channels the NBKR should concentrate on improving the liquidity forecasting function and find better ways to eliminate the structural excess liquidity by using a longer maturity of securities for open market operations (not just NBKR notes). Furthermore, the mechanism of open market operations should be re-examined in general, and in particular for fine tuning operations, as they may need to be conducted more often and amounts withdrawn should be more precise.

\section{The NBKR should, together with the government, look into ways to improve public} confidence in the banking system. The NBKR faces a number of challenges that are not fully under its control. Primarily, the swift resolution of problem banks is necessary, as well as reducing the government footprint in the banking sector. In order to strengthen public confidence about its competence, the NBKR should increase communications with banks and the public about its policy and the overall health of the economy. Paying salaries and pensions via commercial banks may create a habit of the population to open accounts and leave some money in banks. While reducing dollarization and currency in circulation will take time and more comprehensive reforms, the NBKR can implement measures to make KGS assets more attractive to banks than dollar assets, e.g., by differentiating the reserve requirement rates.

17. The development of the secondary financial market could help to reduce dollarization and strengthen the transmission channels at the same time. The government should explore ways to increase the amount of T-bills available in the secondary market, as well as the amount available to the NBKR for conducting monetary policy.

\section{Over the medium to longer term, the NKBR should look into transitioning to an} inflation targeting framework for monetary policy. The NBKR should continue to build its capacity for inflation targeting via developing a proper macroeconomic model for the Kyrgyz Republic and further improving the quality of statistics for decision making. In parallel, the NBKR should look into better ways to forecast inflation, but these will require improvements in the price statistics and full elimination of controlled prices (energy).

19. The NBKRs independence should be preserved, both with regard to goal independence and instrument independence. The NBKR should have the freedom to select the objectives of monetary policy, whether it is low inflation, the target rate of unemployment, the level of GDP etc. The NBKR cannot provide credit to the economy in support of growth without endangering 
macroeconomic stability. Instrument independence is the freedom to pick the appropriate policies that produce a certain economic outcome. This freedom should be preserved in particular with regard to setting the policy rate. The primary objective should be inflation and monetary targets, and not the development of the economy or the cost of financing of the budget. 


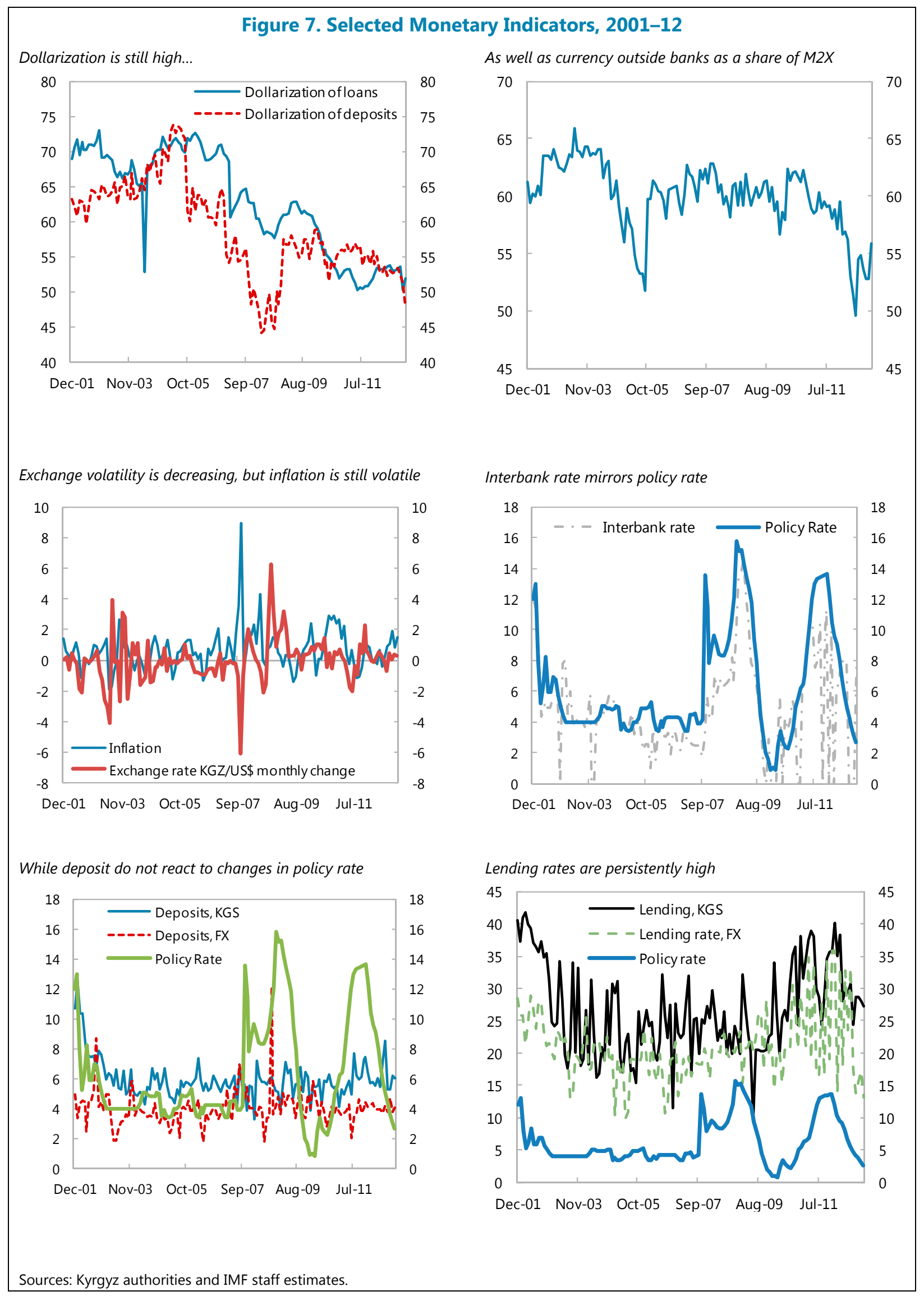




\section{References}

Arnone, Marco, Laurens, Bernard J., and Jean-Francois Segalotto, 2006, Measures of Central Bank autonomy: Empirical evidence for OECD, Developing and Emerging Economies, IMF Working Paper, No. 06/228

Bernanke, Ben S., and Alan Blinder, 1988, "Credit, Money, and Aggregate Demand," American Economic Review (May), pp. 435-439.

Bernanke, Ben S., and Mark Gertler, 1995, "Inside the Black Box: The Credit Channel of Monetary Policy Transmission," NBER Working Paper No. 5146, p. 47 (Cambridge, Massachusetts: National Bureau of Economic Research)

Beck ,Thorsten, Demirguc-Kunt,Asli, Levine, Ross Eric, Cihak, martin and Feyen, Erik H.B., "A Database on Financial Development and Structure (updated September 2012)"

Feige, Edgar L., "The Dynamics of Currency Substitution and De facto Dollarization and Euroization in Transition Countries, 2003, Comparative Economic Studies

Floerkermeier, Holger and Era Dabla-Norris, 2006, "Transmission mechanisms of monetary policy in Armenia: Evidence from VAR Analysis," IMF Working Paper, No. 06/248

International Monetary Fund, 2007, Kyrgyz Republic: "Monetary Framework, Operations, and Liquidity management"

2005, Kyrgyz Republic: "Monetary Operations, Banking System Development, and Central Bank Autonomy"

2010, Regional Economic Outlook, October 2010: Monetary Policy effectiveness in Sub-Saharan Africa

Isakova, Asel, (2008), "Monetary Policy Efficiency in the Economies of Central Asia," Czech Journal of Economics and Finance, Vol. 58, No. 11-12

Mishra, Prachi, Montiel, Peter J. and Spilimbergo, Antonio, 2010, "Monetary Transmission in Low Income Countries", IMF Working Paper, No. 10/233 
Mishra, Prachi, and Montiel, Peter J., 2012, "How Effective is Monetary Transmission in Low-Income countries? A Survey of Empirical Evidence, IMF Working Paper, No. 12/143

The National Bank of Kyrgyz Republic, Annual Report, 2011

Main Monetary Policy Guidelines for 2012-14

Romer, C. D. and D. H. Romer, 1990, "New Evidence on the Monetary Transmission Mechanism," Brookings Papers on Economic Activity No. 1, pp. 149-213.

Samkharadze, Besiik, 2008, "Monetary transmission mechanism in Georgia: Analyzing pass-through of different channels," Center for Operations Research and Econometrics, Belgium. Available at: http://www.nbg.gov.ge/uploads/workingpaper/nbgwp02.08.pdf) 


\section{EXCHANGE RATE ASSESSMENT AND RESERVE ADEQUACY IN THE KYRGYZ REPUBLIC ${ }^{1}$}

\section{A. Exchange Rate Assessment}

The Kyrgyz Republic is a small open economy that is vulnerable to external shocks. Staff continues to support the authorities' policy of exchange rate flexibility with only limited interventions to smooth large fluctuations. Nominal flexibility has helped to maintain external competitiveness and to ensure that the real exchange rate is in line with fundamentals.

\section{Introduction}

1. The Kyrgyz Republic continues to be one of the most open economies in the world. In 2012, total trade amounted to 150 percent of GDP, compared to 100 percent on average for the Commonwealth of Independent States (CIS) countries and 62 percent for the world as a whole (Figure 1). This openness, however, exposes the economy to a variety of external shocks, most notably in the form of commodity price fluctuations and demand changes in trading partner countries. Exports of the Kyrgyz Republic are dominated by gold production, which accounts for more than 30 percent of the export value of goods in recent years. Commodities and manufactured goods are the main imported goods. Therefore, commodity prices affect both sides of the trade in the Kyrgyz Republic.

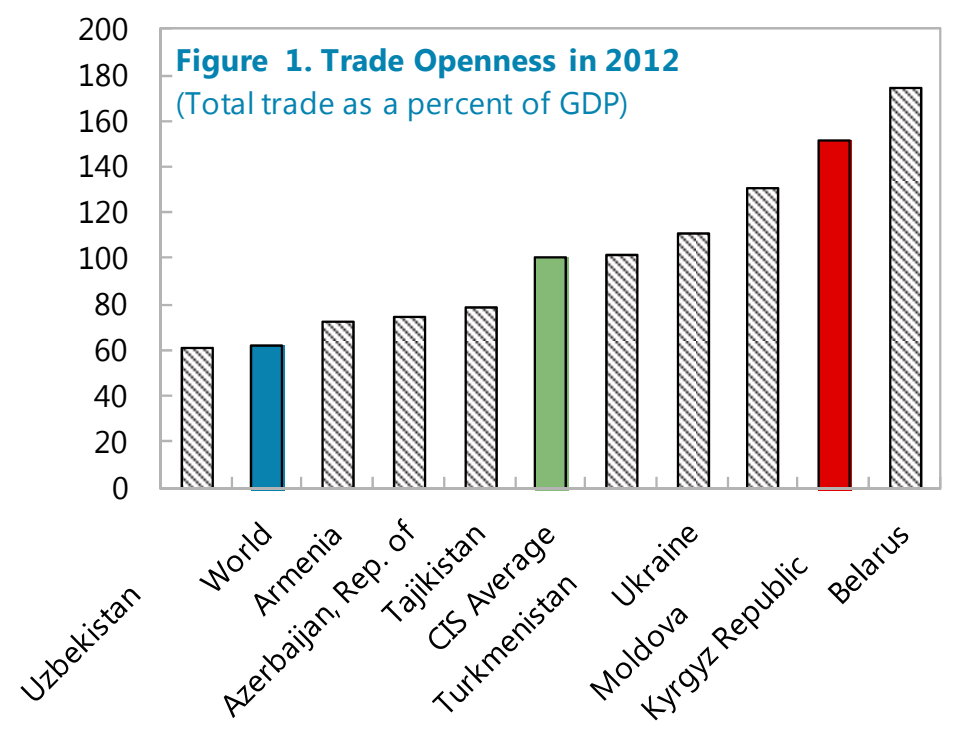

Source: WEO.

\footnotetext{
${ }^{1}$ Prepared by Qianying Chen. This note updates the note in "Kyrgyz Republic: Selected Issues", 2011 IMF Country Report No. 11/156.
} 
2. Export and import prices of the Kyrgyz Republic have been volatile. Both the export prices and import prices picked up strongly after 2009, and have been rising by more than 18 percent and 14 percent in 2010 and 2011, respectively (Figure 2). In 2012, both prices fell by more than 1.5 percent. In the past decade, import prices were in general more volatile, contributing to the volatility of domestic inflation. The current account maintained at a negative position in the recent past (Figure 3).
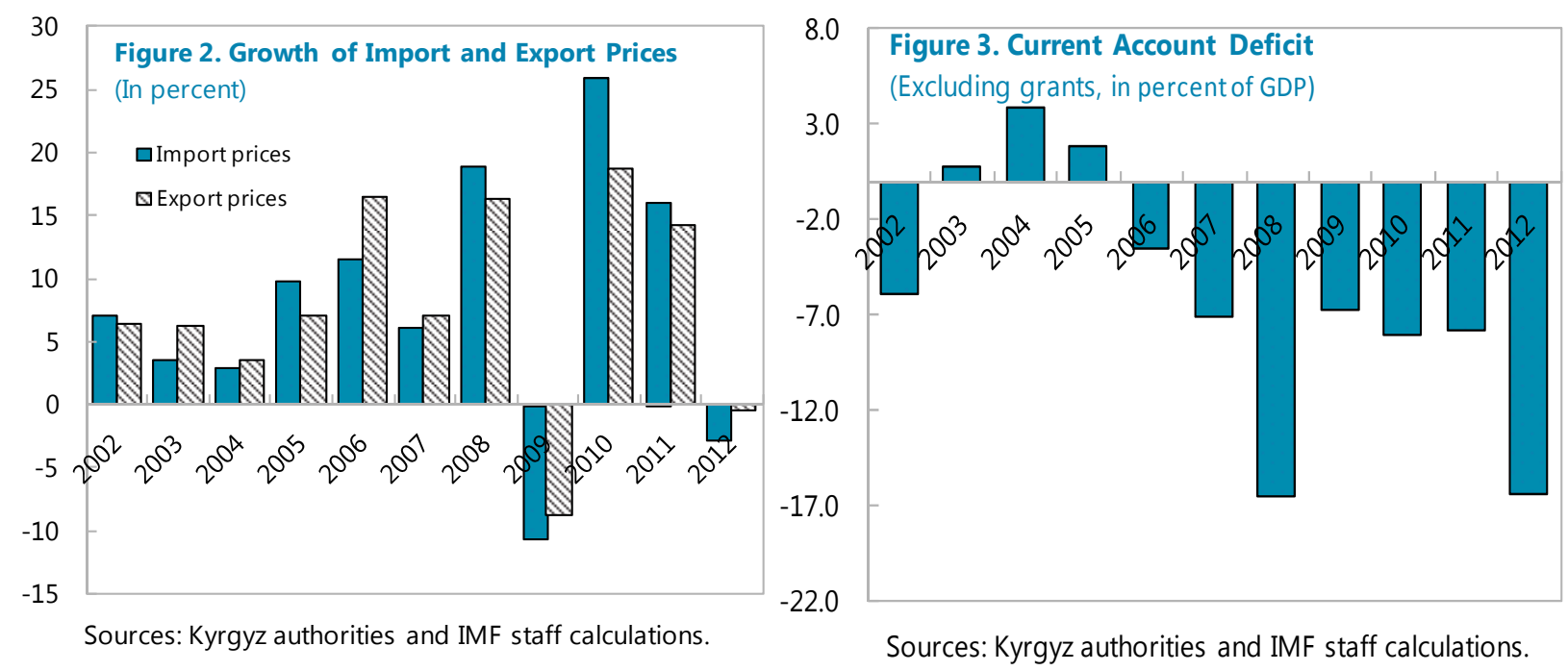

\section{The flexible exchange rate regime with limited central bank intervention has}

supported competitiveness. The de jure exchange rate regime for the Kyrgyz som is floating, with ad hoc interventions to smooth large fluctuations. The de facto regime is considered to be other managed arrangement. Nominal exchange rate flexibility has served the economy well in terms of stabilizing external shocks and maintaining competitiveness. The depreciation in 2008 after the global financial crisis and from 2009 through 2011 sustained export growth during a period of weak external demand and high domestic prices, as reflected in a stable REER in the past years. The exchange rate remained broadly stable in 2011 and 2012 (Figure 4), although the estimated current account deficit has widened substantially in 2012.
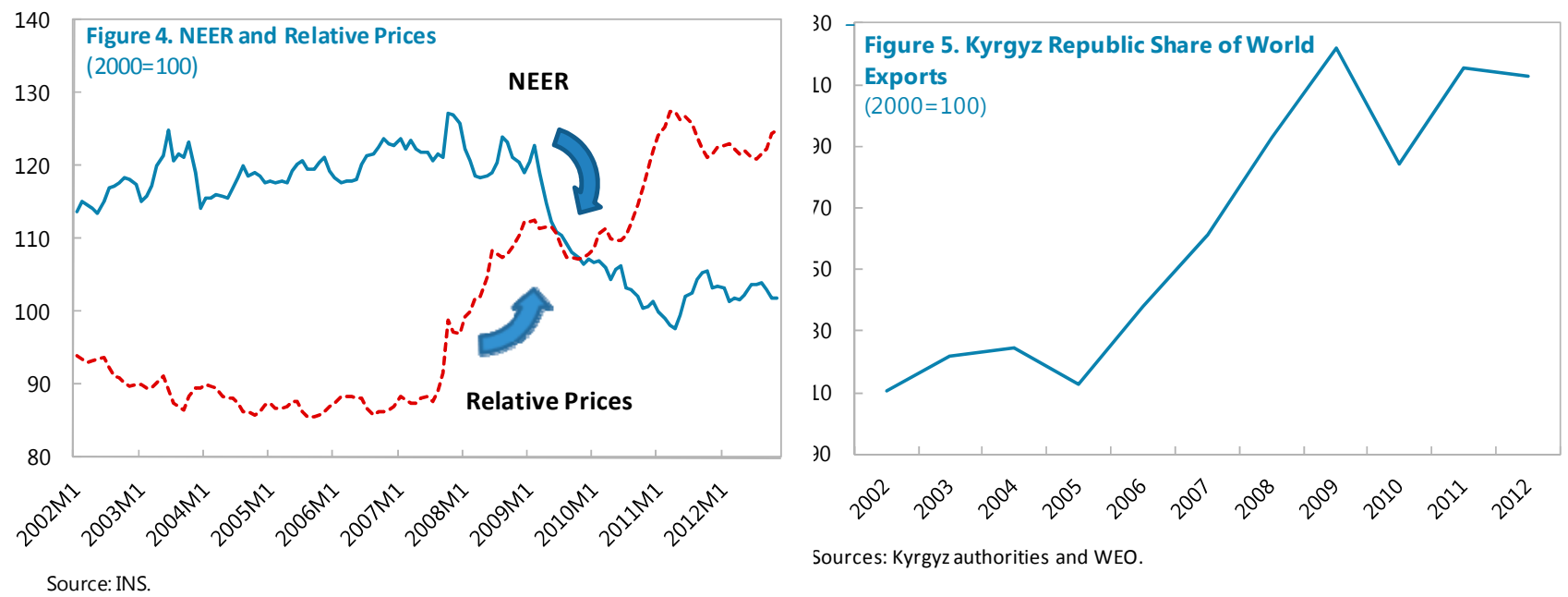


\section{Real Exchange Rate Assessment}

\section{To assess the level of the real effective exchange rate, three econometric}

methodologies are used: the equilibrium real exchange rate (ERER) approach, the macroeconomic balance (MB) approach, and the external sustainability (ES) approach.

- Under the ERER approach, exchange rate misalignment is measured as the deviation of the actual exchange rate from the equilibrium value. The equilibrium value of the REER is then modeled as a function of factors that cause deviations from purchasing power parity, including terms of trade, productivity, government consumption, and the level of initial foreign assets.

- Under the MB approach, the degree to which the REER is in line with fundamentals is inferred as the change in the REER needed to reconcile the underlying current account balance with the estimated current account norm. The equilibrium value of the ratio of the current account balance to output is then modeled.

- Under the ES approach, the current account norm is equated to the ratio of the current account balance to output needed to stabilize the ratio of the net foreign asset position to output around its norm, which is generally equated to its most recently observed value. The degree to which the REER is in line with fundamentals is then computed as under the MB approach.

\section{The econometric assessments indicate that the real exchange rate is broadly in line}

with fundamentals. Applying the three methods to assess the exchange rates in 2011 and 2012 suggests a small undervaluation of 2.1 percent on average. In particular, the ERER approach indicates a 7.7 percent undervaluation. However, it is statistically insignificant from zero. The MB approach indicates a 8 percent undervaluation to close the gap of the current account balance and the ES approach shows over 9 percent overvaluation (Table 1). Therefore, there is no conclusive evidence for a significant exchange rate misalignment of the Kyrgyz som.

Text Table 1. Kyrgyz Republic: Econometric Assessments of the Real Exchange Rate

$$
\text { Disequilibrium }^{1}
$$

\begin{tabular}{lr}
\hline CGER Methodology & Estimate \\
\hline Equilibrium Real Exchange Rate Approach & -7.7 \\
Macroeconomic Balance Approach & -8 \\
External Sustainability Approach & 9.4 \\
\hline Average & -2.1 \\
\hline
\end{tabular}

1/ Positive numbers indicate an overvaluation. Staff estimates using CGER toolkit. 


\section{Conclusions and Policy Implications}

\section{Nominal exchange rate flexibility has bolstered external competitiveness and helped} to keep the real exchange rate aligned with fundamentals. Looking forward, the authorities should continue to monitor external developments closely and ensure that the exchange rate adjusts to changing fundamentals, including volatile import prices.

\section{While nominal flexibility has been beneficial, other measures should be pursued to} maintain and increase external competitiveness and mitigate imported inflation. Specifically, continued efforts to improve the business climate will help. ${ }^{2}$ Monetary policy and policies to improve domestic infrastructure (especially on energy products) and education will help reduce the reliance on foreign imports, and hence reduce the volatility in inflation.

\section{B. International Reserve Adequacy in the Kyrgyz Republic ${ }^{3}$}

The current level of reserves in the Kyrgyz Republic is adequate, but buffers are limited. Reserve accumulation was strong during the past decade, but decelerated in 2012. The assessment of future reserves adequacy shows that the economy remains vulnerable to external shocks. More attention should be paid to increase domestic savings and thus accumulate reserves to avoid future balance of payment instability.

\section{Introduction}

8. Gross international reserves (GIR) in the Kyrgyz Republic have increased more than seven-fold in the last decade. Except in the immediate aftermath of the global economic crisis, GIR in the Kyrgyz Republic increased steadily and reached US\$2,061 million at end-2012 (Figure 6). Reserves grew at a slower pace after 2011.

\section{Remittances, gold exports and} official development assistance continue

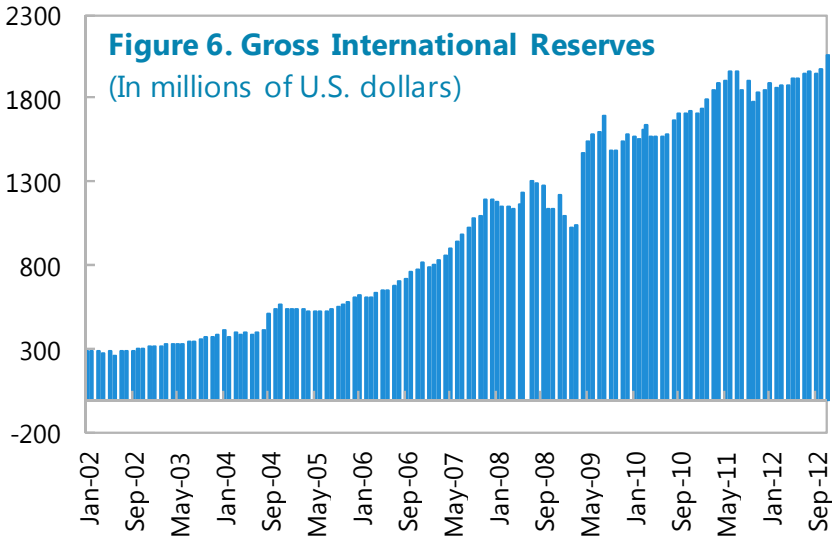

Sources: Kyrgyz authorities and IMF staff calculations. to be important sources of reserve accumulation. The drop in gold exports contributed to lower growth of reserves in 2012. Exports, which are close to 50 percent of GDP (Figure 7), are the most important source of foreign reserves. In particular, gold exports, which are largely driven by a single

\footnotetext{
${ }^{2}$ The business environment in Kyrgyz Republic has become less competitive in the past two years, falling from 44 out of 183 countries in 2011 to 70 in 2013, according to the World Bank's Doing Business Report. In particular, paying taxes, resolving insolvency, getting credit, and cross border trade, which are ranked lower than before, are areas that need to be improved. See http://www.doingbusiness.org/data/exploreeconomies/kyrgyz-republic.

${ }^{3}$ This note updates the note in"Kyrgyz Republic: Selected Issues", 2011 IMF Country Report No. 11/156.
} 
foreign-owned company, contributed to more than 30 percent of exports and around 10 percent of GDP in recent years. At around 30 percent of GDP, remittances are the second most important contributor to GDP besides exports-about 95 percent of the inflows come from Russia. Official development assistance in the form of program and project loans and grants is another important source of inflows, averaging about 8 percent of GDP during the last decade.

\section{Imports, in particular fuel and food, are the main drains on foreign reserves and} continued to grow. Import values have increased mainly because of higher commodity prices (Figure 8).

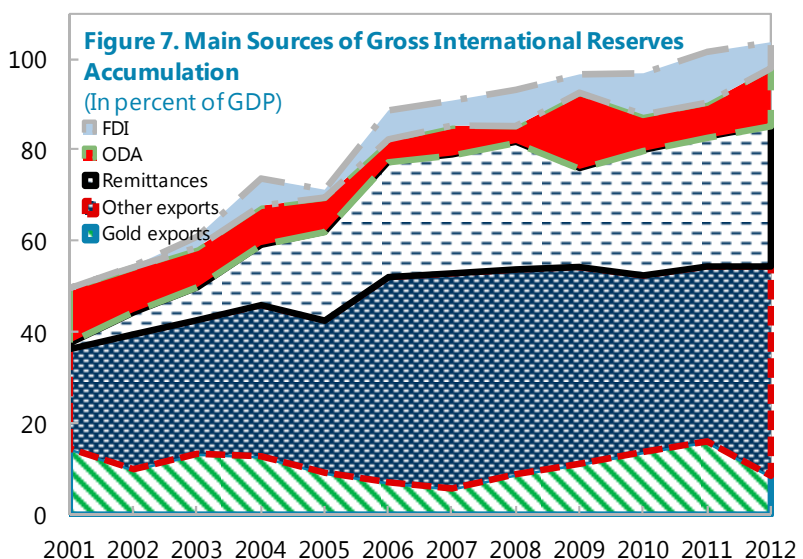

Sources: Kyrgyz authorities and IMF staff calculations.

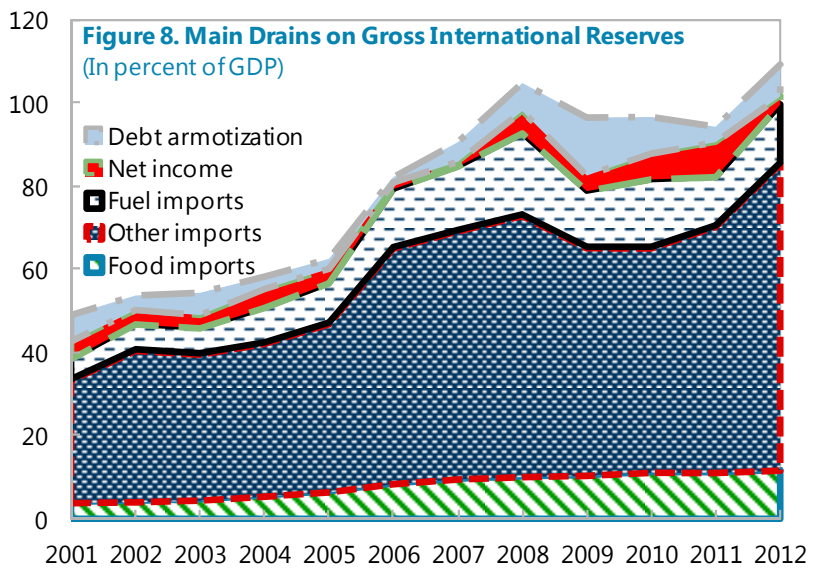

Sources: Kyrgyz authorities and IMF staff calculations.

11. Overall, rising import prices and the decline of gold exports have played an important role in slowing reserve accumulation. The decline in gold production had a significant impact on exports, despite higher gold prices. Higher food and fuel prices added stress to the balance of payments given the Kyrgyz Republic's dependency on these imported goods.

\section{Reserve Adequacy Assessment}

\section{The current level of reserves in the Kyrgyz Republic exceeds all conventional reserve adequacy indicators, but the reserve buffer shrank (Table 2).}

- The ratio of gross international reserves to subsequent year's imports in months was 3.4 and 3.8 in 2011 and 2012 respectively, which is above the recommended level of three months. ${ }^{4}$ However, this ratio fell compared to 2009.

\footnotetext{
${ }^{4}$ Changes in ratios compared to the 2011 assessment are due to data revision and improvements in the methodology.
} 
- The ratio of GIR to broad money was around 100 percent in 2012, well above the 20 percent considered the upper value of a conventional range. Similar to the ratio to imports, it fell since 2011 to the lowest level in the past decade.

- Reserves represented over 450 percent of foreign currency denominated deposits in the past two years.

- The ratio of reserves to short-term external debt at remaining maturity for 2011 and 2012 were around 900 percent, well above the 100-percent Greenspan-Guidotti threshold. Nonetheless, the high ratio reflects limited market access and hence the limited role of short-term external debt as a source of funds and drain on foreign reserves.

Text Table 2. Kyrgyz Republic: Gross International Reserves

\begin{tabular}{|c|c|c|c|c|c|c|c|c|c|c|c|c|}
\hline & 2001 & 2002 & 2003 & 2004 & 2005 & 2006 & 2007 & 2008 & 2009 & 2010 & 2011 & 2012 \\
\hline \multicolumn{13}{|l|}{ Gross International Reserves } \\
\hline in million U.S. dollars & 285 & 290 & 359 & 544 & 608 & 814 & 1,194 & 1,222 & 1,584 & 1,716 & 1,831 & 2,061 \\
\hline in percent of GDP & 18.6 & 18.0 & 18.7 & 24.6 & 24.7 & 28.7 & 31.4 & 23.8 & 33.8 & 35.8 & 29.5 & 31.8 \\
\hline in months of subsequent year imports & 4.5 & 3.9 & 3.8 & 4.7 & 3.2 & 3.0 & 3.0 & 4.0 & 4.9 & 4.0 & 3.4 & 3.8 \\
\hline in percent of broad money & 165.8 & 121.2 & 106.7 & 114.8 & 118.0 & 96.0 & 97.9 & 99.9 & 122.2 & 116.8 & 107.0 & 99.2 \\
\hline in percent of foreign currency deposits & 675.8 & 495.2 & 436.2 & 382.8 & 470.9 & 379.0 & 510.4 & 472.5 & 511.9 & 523.0 & 489.1 & 464.8 \\
\hline in percent of short-term external debt & 615.4 & 441.9 & 301.9 & 365.1 & 310.0 & 382.2 & 382.4 & 317.5 & 376.0 & 935.6 & 990.9 & 870.3 \\
\hline \multicolumn{13}{|l|}{ GIR and Banks Liquid Assets } \\
\hline in million U.S. dollars & 285 & 294 & 372 & 558 & 628 & 851 & 1,224 & 1,264 & 1,628 & 1,761 & 1,910 & 2,142 \\
\hline in percent of broad money & 165.8 & 123.0 & 110.5 & 117.9 & 121.8 & 100.3 & 100.3 & 103.3 & 125.6 & 119.9 & 111.7 & 103.1 \\
\hline in percent of short-term external debt & 615.4 & 448.2 & 312.6 & 374.9 & 319.9 & 399.5 & 392.0 & 328.4 & 386.4 & 959.9 & $1,033.9$ & 904.5 \\
\hline
\end{tabular}

13. The current level of reserves appears to be adequate based on composite indicators, but not comfortably higher than the associated threshold values. The composite indicators consider contemporaneous effects, typically under crisis circumstances, of a drain on reserves from a few potential sources.

- The Lipschitz, Messmacher, and Mourmouras composite reserve adequacy ratio is above the threshold levels. The composite indicator proposed by Lipschitz, Messmacher, and Mourmouras (2006) takes into account the need to finance import consumption in the event of a drop in revenues. It looks at reserve coverage relative to the sum of 100 percent of the prospective external debt service, 10 percent of broad money, and 20 percent of imports of goods and services. The indicators were about 117 percent and 121 percent in 2011 and 2012, respectively, suggesting that reserves were adequate (compared to the threshold of 100 percent) to cover drains from the above mentioned sources (Table 3).

- Another recent reserve adequacy measure for low income countries shows that the reserve buffer is only marginally higher than the thresholds. This indicator shows the calibrated optimal level of reserves that balances the benefit and cost of holding them. The benefit of holding reserves is preventing a sharp drop in 
absorption due to adverse external shocks, and the cost of holding it include the foregone investment opportunities and interest rate costs. Both indicators for fixed exchange rate regimes and flexible exchange rate regimes are relevant for the Kyrgyz Republic. Because the exchange rate regime is classified as other managed arrangement, which indicates flexibility with limited central bank intervention. The indicator for flexible exchange rate regimes shows that the Kyrgyz reserves are adequate. The indicator for fixed exchange rate regimes shows that reserves would not be adequate. Given the mixed exchange rate regime the simple average indicator is calculated for 2011 and 2012. This indicator suggests that reserve level has been lower than the threshold of 100 percent in 2011 and marginally above the threshold in 2012. There is no qualitative change in the result even if a higher weight is given to the flexible exchange rate regime.

- Based on a new composite indicator recently developed by IMF staff, the Kyrgyz Republic's reserve adequacy is at a comfortable level. The value of these indicators in 2011 and 2012 were close to 400 percent, significantly above the 100-150 percent range generally considered adequate. This measure takes into account the drains on reserves stemming from potential external demand shocks and capital flight in a crisis. However, this indicator is more useful for emerging markets where portfolio flows play an important role in the balance of payment.

\section{The assessment of future reserves adequacy relies on several most relevant indicators}

for the Kyrgyz Republic: the level of reserves in months of subsequent year's import, the ratio of reserves over the Lipschitz, Messmacher, and Mourmouras indicator, and the same ratio over the threshold of calibrated reserves for LICs (Table 4). Results show that the reserves will remain at four months of exports until 2016, and go up to 4.1 and 4.2 by 2018. The other two indicators show a similar picture that the reserve level is either at or slightly higher than the adequacy thresholds, thereby not providing a strong buffer.

\begin{tabular}{|c|c|c|c|c|c|c|c|c|c|c|c|c|}
\hline & 2001 & 2002 & 2003 & 2004 & 2005 & 2006 & 2007 & 2008 & 2009 & 2010 & 2011 & 2012 \\
\hline \multicolumn{13}{|l|}{ Gross International Reserves in percent of } \\
\hline Lipschitz, Messmacher, and Mourmouras threshold & 105.7 & 110.2 & 109.4 & 150.5 & 147.5 & 133.4 & 138.9 & 103.4 & 149.4 & 151.1 & 116.5 & 121.3 \\
\hline IMF composite-flexible exchange rate & 363.0 & 302.9 & 266.1 & 318.5 & 320.2 & 319.6 & 334.5 & 269.4 & 354.7 & 450.3 & 381.6 & 389.8 \\
\hline Calibrated reserves for LCS with fixed exchange rate 1/ & 82.5 & 71.6 & 69.5 & 84.9 & 58.9 & 55.4 & 54.7 & 72.1 & 88.2 & 73.4 & 61.9 & 69.8 \\
\hline Calibrated reserves for LCS with flexible exchange rate 1 / & 216.0 & 187.5 & 182.1 & 222.4 & 154.3 & 145.2 & 143.3 & 189.0 & 231.0 & 192.3 & 162.2 & 182.8 \\
\hline Calibrated reserves for LICs average for fixed and flexible exchange rates 1 / & 119.4 & 103.6 & 100.6 & 122.9 & 85.3 & 80.2 & 79.2 & 104.4 & 127.7 & 106.3 & 89.6 & 101.0 \\
\hline \multicolumn{13}{|l|}{ Memorandum items (in millions of U.S. dollars): } \\
\hline Gross international reserves & 285 & 290 & 359 & 544 & 608 & 814 & 1,194 & 1,222 & 1,584 & 1,716 & 1,831 & 2,061 \\
\hline Lipschitz, Messmacher, and Mourmouras threshold & 270 & 263 & 328 & 361 & 413 & 610 & 860 & 1,182 & 1,060 & 1,136 & 1,572 & 1,700 \\
\hline IMF composite - flexible exchange rate & 79 & 96 & 135 & 171 & 190 & 255 & 357 & 454 & 447 & 381 & 480 & 529 \\
\hline Calibrated reserves for LICs with fixed exchange rate & 346 & 405 & 517 & 640 & 1,033 & 1,469 & 2,182 & 1,694 & 1,795 & 2,337 & 2,956 & 2,954 \\
\hline Calibrated reserves for LICs with flexible exchange rate & 132 & 155 & 197 & 244 & 394 & 561 & 833 & 647 & 686 & 892 & 1,129 & 1,128 \\
\hline Calibrated reserves for LCS average for fixed and flexible exchange rates & 239 & 280 & 357 & 442 & 714 & 1,015 & 1,507 & 1,171 & 1,240 & 1,615 & 2,043 & 2,041 \\
\hline
\end{tabular}




\section{Scenario Analysis}

15. This section assess reserve adequacy under different country-specific stress scenarios.

- The first scenario is a stagnation of global growth. Slower global growth could have spillovers to the Kyrgyz Republic through weakening the export demand and lower remittances from Russia. The scenario assumes a one-off $1 / 2$ standard deviation drop in exports of nongold goods (10 percent) and services of (16 percent). ${ }^{5}$ The adverse shocks push the level of all indicators below the threshold values in 2013. It is uncertain that reserves will recover to an adequate level over the medium term, because the LIC indicator signals that reserves will be below the threshold throughout 2018.

- The second scenario tests the impact of a combined global oil price and food price shock. The assumption is a one-off rise in the oil price to US\$140 per barrel in 2013, and food prices remaining at 2012 levels through 2018. This scenario also leads to a substantial deterioration in reserve adequacy in 2013. The impact is a bit smaller compared to the export demand/remittances shock, and reserve adequacy will be insufficient in 2018 as suggested by the LIC indicator, although adequate as shown by two other indicators.

- The third scenario is a repetition of the $\mathbf{2 0 1 2}$ disruption in gold production in 2014. If gold production in 2014 is going to be at the same level as in 2012 (315 thousand ounces or about half), international reserves would stay between three to four months of subsequent year's import from 2013 onwards. Similarly, one out of the three indicators suggests that reserve levels will not recover to the adequate level by 2018.

\footnotetext{
${ }^{5}$ The use of a $1 / 2$ standard deviation is justified, because the past decade was characterized by two revolutions and a financial crisis.
} 
Text Table 4. Kyrgyz Republic: Composite and Calibrated Reserve Adequacy Indicators Under Different Scenario

\begin{tabular}{|c|c|c|c|c|c|c|c|}
\hline & 2012 & 2013 & 2014 & 2015 & 2016 & 2017 & 2018 \\
\hline \multicolumn{8}{|l|}{ Baseline } \\
\hline Gross International Reserves in months of subsequent year's imports & 3.8 & 3.8 & 4.0 & 4.0 & 4.0 & 4.1 & 4.2 \\
\hline \multicolumn{8}{|l|}{ Gross International Reserves in percent of } \\
\hline Lipschitz, Messmacher, and Mourmouras threshold & 121.3 & 126.0 & 130.8 & 130.5 & 128.4 & 147.0 & 157.5 \\
\hline Calibrated reserves for LICs with fixed exchange rate $1 /$ & 69.8 & 68.8 & 71.9 & 72.6 & 73.3 & 74.8 & 76.3 \\
\hline Calibrated reserves for LICs with flexible exchange rate $1 /$ & 182.8 & 180.2 & 188.3 & 190.2 & 191.9 & 195.8 & 199.7 \\
\hline Calibrated reserves for LICs, average for fixed and flexible exchange rates 1 / & 101.0 & 99.6 & 104.1 & 105.1 & 106.1 & 108.2 & 110.4 \\
\hline Gross international reserves (in millions of U.S. dollars) & 2,061 & 2,160 & 2,389 & 2,565 & 2,753 & 2,989 & 3,456 \\
\hline \multicolumn{8}{|l|}{ Scenario 1. Global Growth Stagnation } \\
\hline Gross International Reserves in months of subsequent year's imports & 3.8 & 2.8 & 2.9 & 3.1 & 3.2 & 3.3 & 3.2 \\
\hline \multicolumn{8}{|l|}{ Gross International Reserves in percent of } \\
\hline Lipschitz, Messmacher, and Mourmouras threshold & 121.3 & 91.7 & 97.1 & 101.9 & 101.6 & 116.3 & 118.6 \\
\hline Calibrated reserves for LICs with fixed exchange rate $1 /$ & 69.8 & 50.0 & 53.4 & 56.7 & 58.0 & 59.2 & 57.4 \\
\hline Calibrated reserves for LICs with flexible exchange rate 1 / & 182.8 & 131.0 & 139.8 & 148.5 & 151.9 & 155.0 & 150.4 \\
\hline Calibrated reserves for LICs, average for fixed and flexible exchange rates 1 / & 101.0 & 72.4 & 77.2 & 82.1 & 84.0 & 85.7 & 83.1 \\
\hline Gross international reserves (in millions of U.S. dollars) & 2,061 & 1,571 & 1,774 & 2,003 & 2,179 & 2,366 & 2,602 \\
\hline \multicolumn{8}{|l|}{ Scenario 2. World Oil Price and Food Price Shock } \\
\hline Gross International Reserves in months of subsequent year's imports & 3.8 & 3.2 & 3.4 & 3.5 & 3.6 & 3.6 & 3.5 \\
\hline \multicolumn{8}{|l|}{ Gross International Reserves in percent of } \\
\hline Lipschitz, Messmacher, and Mourmouras threshold & 121.3 & 107.0 & 111.5 & 115.3 & 113.9 & 129.3 & 130.6 \\
\hline Calibrated reserves for LICs with fixed exchange rate $1 /$ & 69.8 & 58.4 & 61.3 & 64.2 & 65.0 & 65.8 & 63.2 \\
\hline Calibrated reserves for LICs with flexible exchange rate $1 /$ & 182.8 & 153.0 & 160.5 & 168.0 & 170.3 & 172.3 & 165.6 \\
\hline Calibrated reserves for LICs, average for fixed and flexible exchange rates 1 / & 101.0 & 84.6 & 88.7 & 92.9 & 94.1 & 95.2 & 91.5 \\
\hline Gross international reserves (in millions of U.S. dollars) & 2,061 & 1,835 & 2,037 & 2,266 & 2,442 & 2,629 & 2,866 \\
\hline \multicolumn{8}{|l|}{ Scenario 3. Gold Production Disruption } \\
\hline Gross International Reserves in months of subsequent year's imports & 3.8 & 3.8 & 3.1 & 3.2 & 3.3 & 3.4 & 3.3 \\
\hline \multicolumn{8}{|l|}{ Gross International Reserves in percent of } \\
\hline Lipschitz, Messmacher, and Mourmouras threshold & 121.3 & 126.0 & 101.5 & 106.0 & 105.4 & 120.4 & 122.3 \\
\hline Calibrated reserves for LICs with fixed exchange rate $1 /$ & 69.8 & 68.8 & 55.8 & 59.0 & 60.2 & 61.2 & 59.2 \\
\hline Calibrated reserves for LICs with flexible exchange rate $1 /$ & 182.8 & 180.2 & 146.2 & 154.5 & 157.6 & 160.3 & 155.1 \\
\hline Calibrated reserves for LICs, average for fixed and flexible exchange rates 1 / & 101.0 & 99.6 & 80.8 & 85.4 & 87.1 & 88.6 & 85.7 \\
\hline Gross international reserves (in millions of U.S. dollars) & 2,061 & 2,160 & 1,855 & 2,084 & 2,260 & 2,447 & 2,684 \\
\hline
\end{tabular}

Sources: Kyrgyz authorities and Fund staff estimates.

$1 /$ Assumes unit cost of holding reserves of 4 percent.

\section{Conclusions}

\section{The current level of reserves in the Kyrgyz Republic is adequate, but buffers are small and reserves are vulnerable to external shocks. Although reserve accumulation was very strong} during the past decade, being a small open economy, the Kyrgyz Republic is particularly vulnerable to exogenous shocks. In addition, reserve accumulation in the Kyrgyz Republic is also subject to shifts in domestic gold production. The assessment implies that more attention should be paid to increase domestic savings and thus accumulating reserves to avoid future balance of payment instability. 


\section{References}

Lipschitz, Leslie, Miguel Messmacher and Alexandros Mourmouras, 2006, "Reserve Adequacy: Much Higher than you Thought?" Unpublished paper, IMF.

International Monetary Fund, 2011, "Assessing Reserve Adequacy," IMF policy paper.

2011, "Kyrgyz Republic: Selected Issues", IMF Country Report

No. $11 / 156$. 


\section{BUSINESS ENVIRONMENT AND GOVERNANCE ${ }^{1}$}

\section{The Kyrgyz Republic ranks well on rules and regulations associated with doing} business, even though in the last few years the rank has deteriorated. Despite the high rank, many obstacles still exist on the ground because the implementation of these rules and regulations lags behind. Based on the WB Enterprise Survey and Global Governance indicators, the main obstacles are political instability, perceived corruption and government instability, as well as the quality of infrastructure (e.g., access to electricity). According to Transparency international, perceived corruption in 2012 is still very high, with the Kyrgyz Republic ranking 154 out of 170 countries.

2. The Kyrgyz Republic also lags behind on competiveness measures (rank 127 out 144) in comparison with regional peers and globally. The Kyrgyz economy is characterized as factor driven, where quality of institutions and business innovation and sophistication are below average compared with similar countries. EBRD transition indicators suggest that significant work is needed in the area of government and enterprise restructuring, as well as competiveness. Progress has been made in the area of small scale privatization.

\section{Governance indicators in the Kyrgyz Republic are better than in 2005, but have} worsened compared to 2000. In 2011, the Kyrgyz Republic ranked in the bottom ten percentile with regard to the rule of law, and in the bottom quartile in control of corruption and political instability. The Kyrgyz republic does better with regard to regulatory quality and voice and accountability.

4. The open budget index has improved over the last several years, but the Kyrgyz Republic still ranks low and is among the countries with minimal transparency of budget operations. The score (20 out of 100) is well below the scores for most other countries in the region because the Kyrgyz government provides limited information to the public on the national government's budget and financial activities during the course of the budget year. Budget oversight and public engagement are particularly weak.

\section{Representatives of the private sector confirmed that the main impediments to the} business environment continue to prevail, but pointed out some other weaknesses. In addition to weak economic governance and a high level of perceived corruption, they cited problems associated with obtaining and registering land titles as a major obstacle to doing business. Furthermore, finding qualified labor is problematic because of declining quality of education and "brain drain." Finally, business representatives list frequent invasive and time consuming audits by the tax authorities and imposing retroactive penalties among the problem areas.

\footnotetext{
${ }^{1}$ Prepared by Dragana Ostojic.
} 
6. In order to overcome these hurdles to a favorable business environment, the Kyrgyz Republic should:

- Continue to streamline the de facto regulatory burden, and foster the implementation of the existing high quality rules.

- Monitor the business environment via business surveys to identify the bottlenecks in the implementation of legislation and major constrains for doing business.

- Improve access to information in general, and in particular, on government operations and contracts to increase transparency and eliminate perceived corruption.

- Continue with reforms in public procurement and public financial management in order to increase transparency of the budget. 


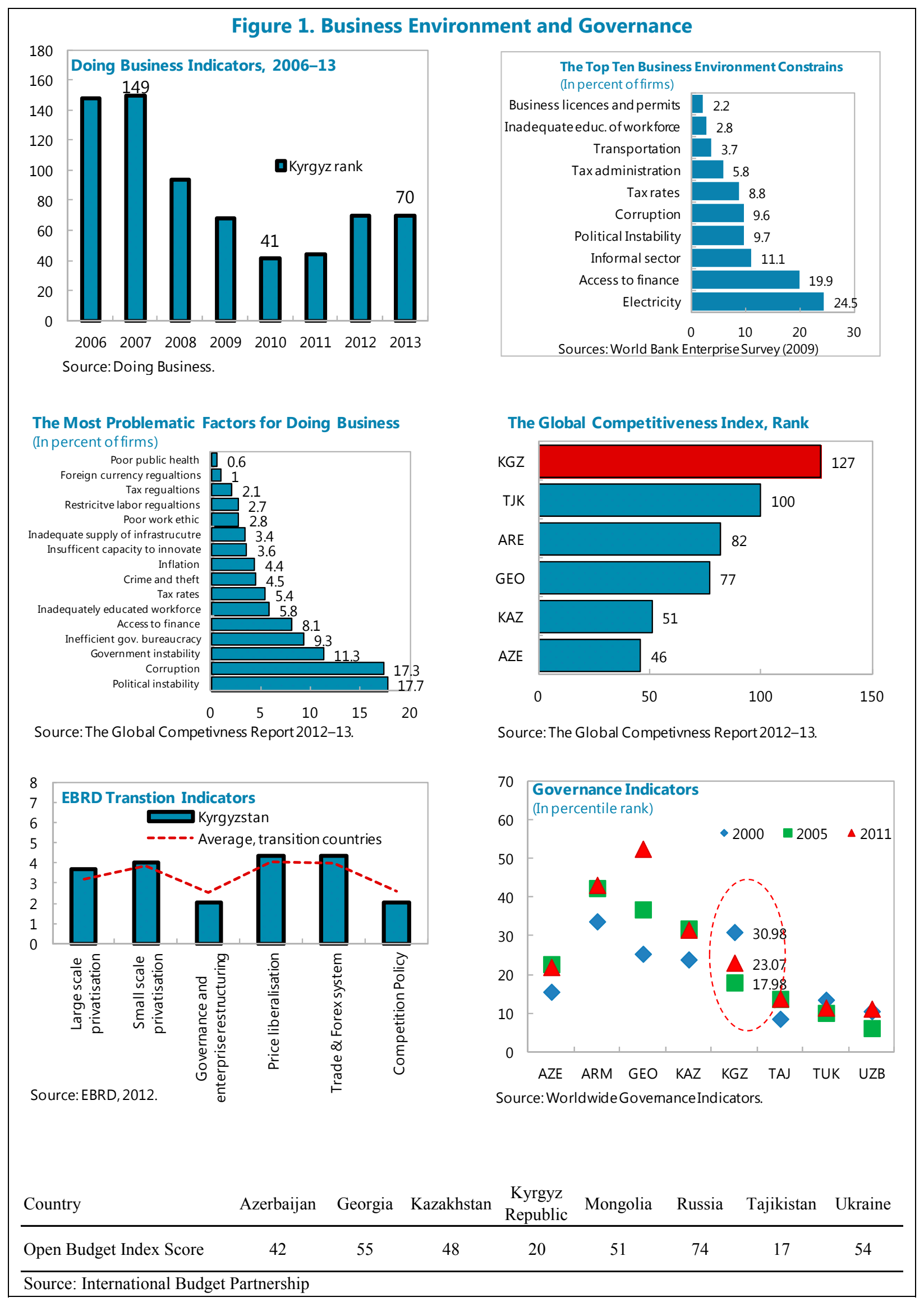




\section{BEST PRACTICES FOR ESTABLISHING DEVELOPMENT} BANKS

1. Public financial institutions (PFIs) are usually established to address market failures that hinder investment. PFIs' objectives are to address perceived structural lack of long-term project financing mostly for infrastructure, agriculture, and small and medium-sized enterprises. In countries, where financial markets remain relatively underdeveloped, PFIs have been providing such financing mainly through direct equity and debt participation, extension of guarantees, and cofinancing with the private sector. In the region, Armenia, Azerbaijan, and Kazakhstan have already had PFIs for a few years; Georgia and Turkmenistan have recently established PFIs; the Kyrgyz Republic and Tajikistan consider establishing PFIs.

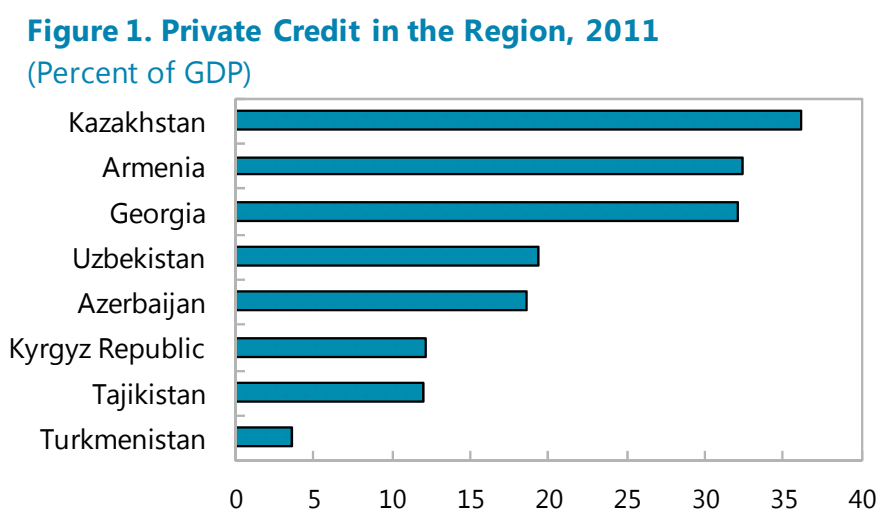

Sources: Kyrgyz authorities and Fund staff estimates.

\section{The Kyrgyz Republic is contemplating to establish a State Development Bank (SDB). A} SDB law that is in line with international best practice has already been approved. The aim is to support growth by developing specific areas of the economy, including affordable mortgage lending, leasing for agriculture, and lending to farmers and entrepreneurs. With lending rates hovering at over 20 percent, profitable sectors such as trade receive more than half of total credit. To ensure that underfunded sectors receive adequate financing, a development fund was set up in the past. However, owing to substantial governance issues, public resources were put at risk and the fund was eventually liquidated.

Figure 2. Credit by Sectors, 2011 Agriculture (In percent of Total)

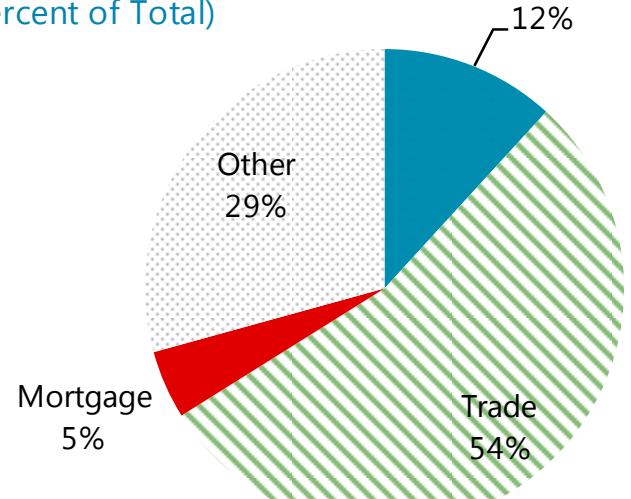

Source: Kyrgyz authorities.

\footnotetext{
${ }^{1}$ Prepared by Bahrom Shukurov based on Box 3.4 contained in "Public Financial Institutions in the CCA: Promoting Financially Sustainable Economic Development" published in the IMF's Regional Economic Outlook of Middle East and Central Asia, November 2012.
} 
3. To minimize risks associated with the SDB, the Kyrgyz government should be guided by best international practice:

- Clear mandate and market-oriented funding mechanisms would help SDB to be successful in its role. Periodic mandate reviews would help reassess the relevance of SDB as market failures dissipate over time, including through other policy measures. Market-oriented funding mechanisms would foster the financial sustainability of the SDB and encourage better planning and risk assessments of projects. While these mechanisms could include donor financing, funding though private deposits should not be allowed. Moreover, adequate regulation and supervision of the SDB will be instrumental in safeguarding public resources.

- Transparent relations with the government and high corporate governance standards would allow for a reliable fiscal impact assessment and help limit undue political pressures. Hard budget constraints will foster efficiency and protect the government against losses. All government support, including initial capitalization of the SDB, need to be channeled through the budget and targeted to strategic projects with large positive externalities. The corporate structure of the SDB should include shareholders, independent boards of directors, and competent managers. The SDB should operate under international standards for accounting and reporting practices. Internal control and risk management systems, budgeting, and undertaking an annual external audit are also the essential ingredients in the SDB's operating framework. 